\title{
Influence of Substituents in Terephthalate Linker on the Structure of MOFs Obtained from Presynthesized Heterometallic Complex
}

\author{
Marina Barsukova ${ }^{1}$, Evgeny Dudko ${ }^{1,2}$, Denis Samsonenko ${ }^{1}{ }^{(}$, Konstantin Kovalenko $^{1}{ }^{\mathbb{D}}$, Alexey Ryadun ${ }^{1}$, \\ Aleksandr Sapianik ${ }^{1, *}$ and Vladimir Fedin ${ }^{1}$ \\ 1 Nikolaev Institute of Inorganic Chemistry, 3 Acad. Lavrentiev Ave., 630090 Novosibirsk, Russia; \\ barsukova@niic.nsc.ru (M.B.); dudko_er@mail.ru (E.D.); denis@niic.nsc.ru (D.S.); \\ k.a.kovalenko@niic.nsc.ru (K.K.); ryadunalexey@mail.ru (A.R.); cluster@niic.nsc.ru (V.F.) \\ 2 Natural Sciences Department, Novosibirsk State University, 1, Pirogova str., 630090 Novosibirsk, Russia \\ * Correspondence: sapianik@niic.nsc.ru
}

Citation: Barsukova, M.; Dudko, E.; Samsonenko, D.; Kovalenko, K.; Ryadun, A.; Sapianik, A.; Fedin, V. Influence of Substituents in Terephthalate Linker on the Structure of MOFs Obtained from Presynthesized Heterometallic Complex. Inorganics 2021, 9, 4. https://doi.org/10.3390/ inorganics 9010004

Received: 25 November 2020 Accepted: 18 December 2020 Published: 2 January 2021

Publisher's Note: MDPI stays neutral with regard to jurisdictional clai$\mathrm{ms}$ in published maps and institutional affiliations.

Copyright: (C) 2021 by the authors. Licensee MDPI, Basel, Switzerland. This article is an open access article distributed under the terms and conditions of the Creative Commons Attribution (CC BY) license (https:// creativecommons.org/licenses/by/ $4.0 /)$.

\begin{abstract}
The synthesis of new porous materials with desired properties is a challenging task. It becomes especially difficult if you need to combine several metals in one framework to obtain a heterometallic node. The use of presynthesized complexes for obtaining of new heterometallic metal-organic frameworks could be essential to solve the problem of tailored synthesis. In our study we use presynthesized heterometallic pivalate complex $\left[\mathrm{Li}_{2} \mathrm{Zn}_{2}(\mathrm{piv})_{6}(\mathrm{py})_{2}\right]$ to obtain new MOFs with heterometallic core as a node of the framework. We are managed to obtain four new heterometallic MOFs: $\left.\left[\mathrm{H}_{2} \mathrm{~N}\left(\mathrm{CH}_{3}\right)_{2}\right]_{2}\left[\mathrm{Li}_{2} \mathrm{Zn}_{2} \text { (bdc) }\right)_{4}\right] \cdot \mathrm{CH}_{3} \mathrm{CN} \cdot \mathrm{DMF}(\mathbf{1}),\left[\mathrm{Li}_{2} \mathrm{Zn}_{2}\left(\mathrm{H}_{2} \mathrm{Br}_{2}-\mathrm{bdc}\right)\left(\mathrm{Br}_{2}-\mathrm{bdc}\right)_{3}\right] \cdot 2 \mathrm{DMF}$ (2), $\left[\mathrm{H}_{2} \mathrm{~N}\left(\mathrm{CH}_{3}\right)_{2}\right]\left[\mathrm{LiZn}_{2}(\mathrm{ndc})_{3}\right] \cdot \mathrm{CH}_{3} \mathrm{CN}(3)$ and $\left[\left\{\mathrm{Li}_{2} \mathrm{Zn}_{2}(\mathrm{dmf})(\mathrm{py})_{2}\right\}\left\{\mathrm{LiZn}(\mathrm{dmf})_{2}\right\}_{2}\left(\mathrm{NO}_{2}-\mathrm{bdc}\right)_{6}\right] \cdot 5 \mathrm{DMF}$ (4). Moreover three of them contain starting tetranuclear core $\left\{\mathrm{Li}_{2} \mathrm{Zn}_{2}\right\}$ and saves its geometry. We also demonstrate the influence of substituent in terephthalate ring on preservation of tetranuclear core. For compound $\mathbf{1}$ it was shown that luminescence of the framework could be quenched when nitrobenzene is included in the pores.
\end{abstract}

Keywords: metal-organic frameworks; heterometallic complexes; luminescence

\section{Introduction}

Metal-organic frameworks (MOFs) represent a relatively new class of compounds that combine the advantages of inorganic compounds due to the presence of metal cations or clusters in the structure, together with almost unlimited possibilities of organic synthesis due to the use of organic ligands as linkers [1]. The large surface area and possibility of inner surface functionalization made MOFs a suitable material for gas storage and separation [2-5]. The use of MOFs as luminescent and electrochemical sensors, conductive materials and heterogeneous catalysts has significantly expanded the field of applications and posed new aims for the structural design of such compounds [6-15]. Synthesis of new porous materials with desired properties is challenging due to the many possible options for how inorganic nodes and organic linkers interact with each other and give the final structure [16]. The task becomes especially difficult if you need to combine several metals in one framework to obtain a heterometallic node $[17,18]$. The resulting materials are even more specialized for certain applications or can be used as multifunctional materials for the simultaneous execution of various tasks $[19,20]$. Thus using of presynthesized complexes could be essential to solve the problem of tailored synthesis. There are five main approaches for obtaining of heterometallic MOFs described in published investigations:

- $\quad$ postsynthetic modification of MOFs by the inclusion of metal ions in the pores of the framework [21-23]; 
- postsynthetic modification of MOFs by the partial or complete replacement of the metal cations in nodes with cations close in ionic radius [24-26];

- the use of salts of several metals in the initial reaction mixture to obtain heterometallic MOFs [27-32];

- the use of a metalloligand containing a metal cation other than the structure-forming metal framework [33-35];

- the use of presynthesized polynuclear heterometallic complexes to obtain MOFs with a given nodes [36-40];

The last approach looks the most promising for obtaining of new heterometallic MOFs with given geometry. In this case the synthesis of designed structure becomes rational and predictable. In our study we use previously obtained and described heterometallic pivalate complex $\left[\mathrm{Li}_{2} \mathrm{Zn}_{2}(\mathrm{piv})_{6}(\mathrm{py})_{2}\right]$ to obtain new MOFs with given metal core as a node of the framework [41]. Terephthalic acid and its analogues with various substituents in the benzene ring are used as linkers (Scheme 1). We investigate the influence of the substituent on the formation of structure and changes occurring with the starting heterometallic core. Using this approaches we managed to obtain four new heterometallic MOFs: $\left[\mathrm{H}_{2} \mathrm{~N}\left(\mathrm{CH}_{3}\right)_{2}\right]_{2}\left[\mathrm{Li}_{2} \mathrm{Zn}_{2}(\mathrm{bdc})_{4}\right] \cdot \mathrm{CH}_{3} \mathrm{CN} \cdot \mathrm{DMF}(\mathbf{1}),\left[\mathrm{Li}_{2} \mathrm{Zn}_{2}\left(\mathrm{H}_{2} \mathrm{Br}_{2}\right.\right.$ bdc) $\left.\left(\mathrm{Br}_{2} \text {-bdc) }\right)_{3}\right] \cdot 2 \mathrm{DMF}(2),\left[\mathrm{H}_{2} \mathrm{~N}\left(\mathrm{CH}_{3}\right)_{2}\right]\left[\mathrm{LiZn}{ }_{2}(\mathrm{ndc})_{3}\right] \cdot \mathrm{CH}_{3} \mathrm{CN}(3)$ and $\left[\left\{\mathrm{Li}_{2} \mathrm{Zn}_{2}(\mathrm{dmf})(\mathrm{py})_{2}\right\}\right.$ $\left.\left\{\mathrm{LiZn}(\mathrm{dmf})_{2}\right\}_{2}\left(\mathrm{NO}_{2}-\mathrm{bdc}\right)_{6}\right] \cdot 5 \mathrm{DMF}(4)$. Sorption and luminescence properties have been studied for $\mathbf{1}$ and $\mathbf{2}$.<smiles>O=C(O)c1ccc(C(=O)O)cc1</smiles>

$b d c^{2-}$

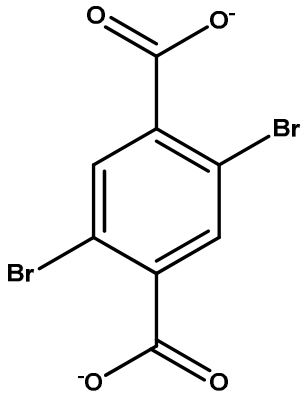

$\mathrm{Br}_{2}-\mathrm{bdc}^{2-}$

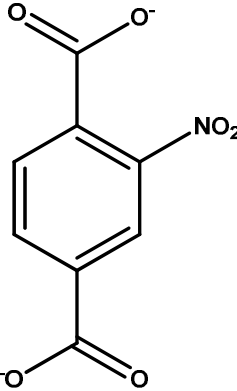

$\mathrm{NO}_{2}-\mathrm{bdc}^{2-}$<smiles>O=C(O)c1ccc(C(=O)O)c2ccccc12</smiles>

$n d c^{2-}$

Scheme 1. Structural formulae of $\mathrm{bdc}^{2-}, \mathrm{Br}_{2}-\mathrm{bdc}^{2-}, \mathrm{NO}_{2}-\mathrm{bdc}^{2-}$, and ndc ${ }^{2-}$ dicarboxylate linkers.

\section{Results}

\section{Synthesis and Crystal Structures}

The compounds $\left[\mathrm{H}_{2} \mathrm{~N}\left(\mathrm{CH}_{3}\right)_{2}\right]_{2}\left[\mathrm{Li}_{2} \mathrm{Zn}_{2}(\mathrm{bdc})_{4}\right] \cdot \mathrm{CH}_{3} \mathrm{CN} \cdot \mathrm{DMF}(\mathbf{1}),\left[\mathrm{Li}_{2} \mathrm{Zn}_{2}\left(\mathrm{H}_{2} \mathrm{Br}_{2}\right.\right.$-bdc) $\left.\left(\mathrm{Br}_{2} \text {-bdc }\right)_{3}\right] \cdot 2 \mathrm{DMF}(2),\left[\mathrm{H}_{2} \mathrm{~N}\left(\mathrm{CH}_{3}\right)_{2}\right]\left[\mathrm{LiZn}_{2}(\mathrm{ndc})_{3}\right] \cdot \mathrm{CH}_{3} \mathrm{CN}$ (3) and $\left[\left\{\mathrm{Li}_{2} \mathrm{Zn}_{2}(\mathrm{dmf})(\mathrm{py})_{2}\right\}\right.$ $\left.\left\{\mathrm{LiZn}(\mathrm{dmf})_{2}\right\}_{2}\left(\mathrm{NO}_{2} \text {-bdc }\right)_{6}\right] \cdot 5 \mathrm{DMF}(4)$ were obtained under solvothermal conditions via the reactions of presynthesized pivalate complex $\left[\mathrm{Li}_{2} \mathrm{Zn}_{2}(\mathrm{piv})_{6}(\mathrm{py})_{2}\right]$ with terephthalic acid or a substituted terephthalic acid in a solvent mixture of acetonitrile and DMF. The pivalate complex was synthesized according to previously published procedure [41]. Obtained crystals except for compound 2 were used for single crystal XRD to determine the crystal structures. In case of compound 2, crystals obtained ina reaction mixture of acetonitrile and DMA (instead of DMF) were used due to the smaller size of crystals obtained with $\mathrm{DMF} /$ acetonitrile mixtures.

The structure of starting pivalate complex $\left[\mathrm{Li}_{2} \mathrm{Zn}_{2}(\mathrm{piv})_{6}(\mathrm{py})_{2}\right]$ presents a tetranuclear heterometallic block consisting of two $\mathrm{Li}^{+}$and two $\mathrm{Zn}^{2+}$ cations all in a tetrahedral environment (Figure 1). Each $\mathrm{Zn}^{2+}$ atom is bound to the $\mathrm{N}$ donor of a pyridine ligand and to three O donors of three carboxylate groups, bond distances $\mathrm{Zn}-\mathrm{O}_{\mathrm{OCO}}$ are from 1.9297(18) to 1.9519(19) $\AA, \mathrm{Zn}-\mathrm{N}_{\mathrm{py}}-2.067(2) \AA . \mathrm{Li}^{+}$atoms coordinate to four O donors from four pivalates, bond distances $\mathrm{Li}-\mathrm{O}_{\mathrm{OCO}}$ vary from $1.889(5)$ to $1.985(5) \AA$. The center of symmetry of the tetranuclear block is at the intersection of the diagonals of the almost square $\left[\mathrm{Li}_{2}\left(\mu_{2}-\mathrm{O}\right)_{2}\right]$ moiety, and the $\left\{\mathrm{Li}_{2} \mathrm{Zn}_{2}\right\}$ core has a planar structure. Three bridging pivalates link the 
$\mathrm{Zn}^{2+}$ and $\mathrm{Li}^{+}$cations, with two carboxylates acting as bridges between two heterometallic centers and one acting as a $\mu_{3}$-bidentate linker bridging two $\mathrm{Li}^{+}$cations through one $\mathrm{O}$ atom. The six carboxylate anions are directed perpendicularly to the $\mathrm{Zn}-\mathrm{Zn}$ axis of the node, while the $\mathrm{Zn}-\mathrm{N}$ bonds are directed along this axis. During synthesis tetranuclear core $\left\{\mathrm{Li}_{2} \mathrm{Zn}_{2}\right\}$ could saves it structure, fragmentizes to dinuclear $\{\mathrm{LiZn}\}$ node or decompose to individual cations (Figure 1).
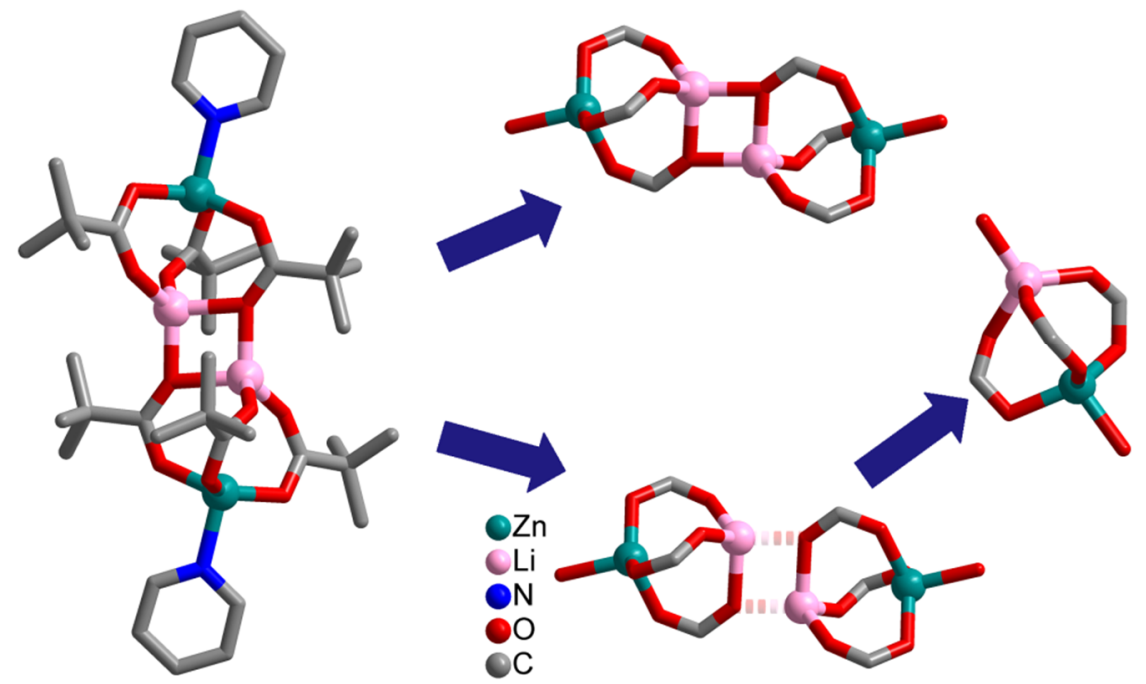

Figure 1. Structure of the presynthesized pivalate complex $\left[\mathrm{Li}_{2} \mathrm{Zn}_{2}(\mathrm{piv})_{6}(\mathrm{py})_{2}\right]$ and obtained heterometallic nodes.

According to single crystal XRD data compound $\left[\mathrm{H}_{2} \mathrm{~N}\left(\mathrm{CH}_{3}\right)_{2}\right]_{2}\left[\mathrm{Li}_{2} \mathrm{Zn}_{2}(\mathrm{bdc})_{4}\right] \cdot \mathrm{CH}_{3} \mathrm{CN}$. DMF (1) crystallizes in the monoclinic space group $P 2_{1} / n$. The starting $\left\{\mathrm{Li}_{2} \mathrm{Zn}_{2}\right\}$ core structure is conserved and becomes an 8-connected tetranuclear heterometallic $\left[\mathrm{Li}_{2} \mathrm{Zn}_{2}(\mathrm{OOCR})_{8}\right]$ node linked by terephthalate moieties (Figure 2a). Thus both pivalate and pyridine moieties are replaced with terephthalate ones. Both $\mathrm{Zn}^{2+}$ cations are in tetrahedral environment of four O donors from carboxylates. $\mathrm{Zn}-\mathrm{O}_{\mathrm{OCO}}$ bond distances values vary from 1.944(2) to $1.974(2) \AA$ which is close to $\mathrm{Zn}-\mathrm{O}_{\mathrm{OCO}}$ bond distances in starting complex. $\mathrm{Li}^{+}$cations are also in a tetrahedral environment of four $\mathrm{O}$ donors, $\mathrm{Li}-\mathrm{O}_{\mathrm{OCO}}$ bond distances are from $1.860(6)$ to $1.953(6) \AA$ which is slightly shorter than in the complex. Almost square angles $\mathrm{O}_{\mathrm{OCO}}-\mathrm{Li}-\mathrm{O}_{\mathrm{OCO}}$ and $\mathrm{Li}-\mathrm{O}_{\mathrm{OCO}}-\mathrm{Li}$ conserve their values of 94.4(2) and 85.6(2) deg., respectively. Each $\left[\mathrm{Li}_{2} \mathrm{Zn}_{2}(\mathrm{OOCR})_{8}\right]$ node is connected by eight terephthalate linkers to form a negatively charged 3D framework (Figure $2 \mathrm{~b}$ ). There are triangular pores with a aperture of approximately $3 \AA$ in the framework. The guest accessible volume is $42 \%$ according to Mercury calculations (Figure S1d) [42]. The inner volume is filled with dimethylammonium ions and guest solvent molecules of DMF and acetonitrile. Dimethylammonium cations are formed during the synthesis in the reaction mixture due to the hydrolysis of DMF molecules. Dimethylammonium ions with partial occupancy $(0.5 ; 0.5)$ fill pores of the framework and transform open pore structure into 0D cavities (Figure S1a). One of the dimethylammonium ions has a hydrogen bond with an $\mathrm{O}$ atom of a linker carboxylate (O . . . N distance is $3.007 \AA$ ). Taking into account the volume occupied with counterions the guest accessible volume ranges from $24.5 \%$ (with the first position of counterion fixed, Figure S1b) to $29.5 \%$ (with the second position of counterion fixed, Figure S1c).

According to single crystal XRD data compound [ $\left.\mathrm{Li}_{2} \mathrm{Zn}_{2}\left(\mathrm{H}_{2} \mathrm{Br}_{2}-\mathrm{bdc}\right)\left(\mathrm{Br}_{2}-\mathrm{bdc}\right)_{3}\right] \cdot 2 \mathrm{DMA}$ (2DMA) crystallizes in the triclinic space group $P-1$. Although the unit cell parameters and space group of compound $\mathbf{2}$ differ from those of compound $\mathbf{1}$ these compounds are isoreticular. The starting $\left\{\mathrm{Li}_{2} \mathrm{Zn}_{2}\right\}$ core also conserves its structure (Figure $3 \mathrm{a}$ ). $\mathrm{Zn}-\mathrm{O}_{\mathrm{OCO}}$ bond distances values are from $1.933(4)$ to $1.984(4) \AA, \mathrm{Li}-\mathrm{O}_{\mathrm{OCO}}$ bond distances are from $1.879(13)$ to $1.956(12) \AA$ which are almost the same as the bond distances in $\mathbf{1}$. Nevertheless the values of the square angles $\mathrm{O}_{\mathrm{OCO}}-\mathrm{Li}-\mathrm{O}_{\mathrm{OCO}}$ and $\mathrm{Li}-\mathrm{O}_{\mathrm{OCO}}-\mathrm{Li}$ change to 92.0(5) and 
88.0(5) deg., respectively. Each [ $\left.\mathrm{Li}_{2} \mathrm{Zn}_{2}(\mathrm{OOCR})_{8}\right]$ node is linked by eight dibromoterephthalates, two of which are protonated. In the $\mathrm{H}_{2} \mathrm{Br}_{2}$-bdc linker the $\mathrm{C}-\mathrm{O}_{\mathrm{OH}}$ distance is $1.218(8)$ $\AA$, which is slightly shorter than for $\mathrm{C}-\mathrm{O}_{\mathrm{OZn}}(1.270(8) \AA)$. Moreover, the $\mathrm{Zn}-\mathrm{O}_{\text {OCO bond }}$ distance for the $\mathrm{H}_{2} \mathrm{Br}_{2}$-bdc linker is the same as the $\mathrm{Br}_{2}-\mathrm{bdc}^{2-}$ linker one. In this case a neutral framework is formed (Figure $3 b$ ). There are only 0D cavities (approx. $5 \times 13 \AA$ ) in the structure due to the Br substituents in the terephthalate linker (Figure S2a). The guest accessible volume is $23.4 \%$ according to Mercury calculations [42]. The inner volume is filled with guest molecules of DMA. The $\mathrm{O}$ atom of a DMA molecule is connected with a protonated carboxylate group of the dibromo- terephthalate linkers by a hydrogen bond (O . . . O distance is $2.843 \AA$ ).

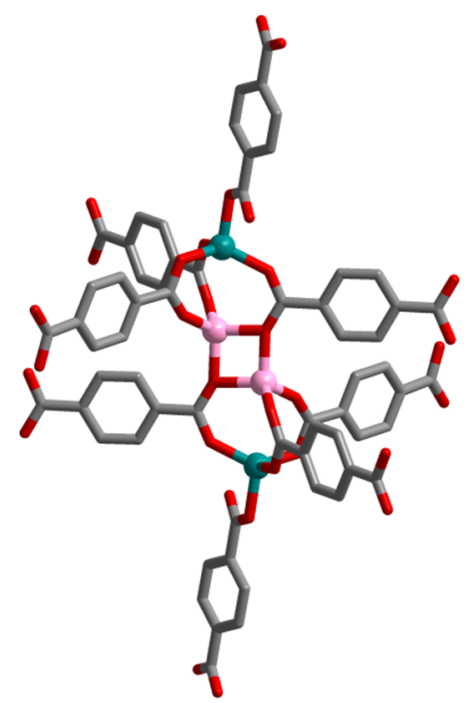

(a)

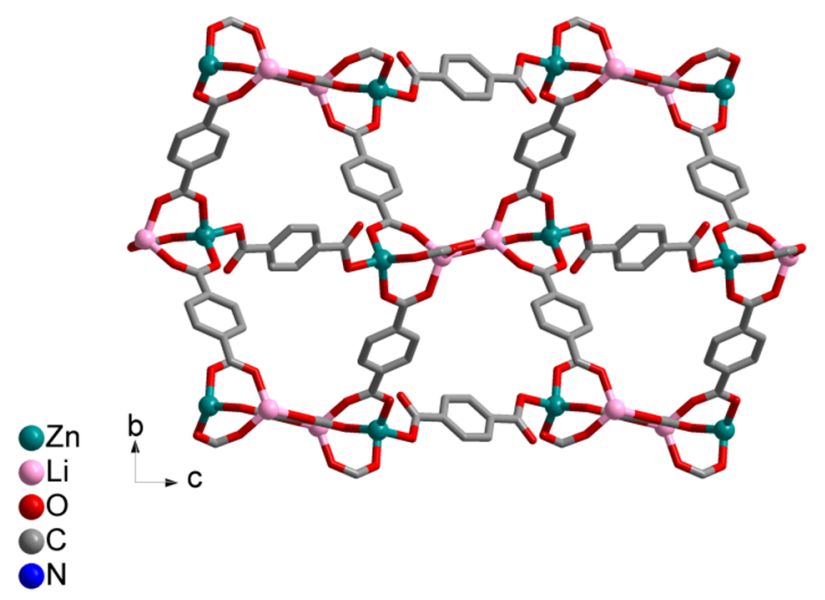

(b)

Figure 2. (a) SBU in compound 1; (b) Structure view of $\mathbf{1}$ along $a$ axis.

According to single crystal XRD data compound [ $\left.\mathrm{Li}_{2} \mathrm{Zn}_{2}\left(\mathrm{H}_{2} \mathrm{Br}_{2}-\mathrm{bdc}\right)\left(\mathrm{Br}_{2}-\mathrm{bdc}\right)_{3}\right] \cdot 2 \mathrm{DMA}$ (2DMA) crystallizes in the triclinic space group $P-1$. Although the unit cell parameters and space group of compound $\mathbf{2}$ differ from those of compound $\mathbf{1}$ these compounds are isoreticular. The starting $\left\{\mathrm{Li}_{2} \mathrm{Zn}_{2}\right\}$ core also conserves its structure (Figure $3 \mathrm{a}$ ). $\mathrm{Zn}-\mathrm{O}_{\mathrm{OCO}}$ bond distances values are from $1.933(4)$ to $1.984(4) \AA, \mathrm{Li}-\mathrm{O}_{\mathrm{OCO}}$ bond distances are from $1.879(13)$ to $1.956(12) \AA$ which are almost the same as the bond distances in $\mathbf{1}$. Nevertheless the values of the square angles $\mathrm{O}_{\mathrm{OCO}}-\mathrm{Li}-\mathrm{O}_{\mathrm{OCO}}$ and $\mathrm{Li}-\mathrm{O}_{\mathrm{OCO}}-\mathrm{Li}$ change to $92.0(5)$ and 88.0(5) deg., respectively. Each $\left[\mathrm{Li}_{2} \mathrm{Zn}_{2}(\mathrm{OOCR})_{8}\right]$ node is linked by eight dibromoterephthalates, two of which are protonated. In the $\mathrm{H}_{2} \mathrm{Br}_{2}$-bdc linker the $\mathrm{C}-\mathrm{O}_{\mathrm{OH}}$ distance is 1.218(8) $\AA$, which is slightly shorter than for $\mathrm{C}-\mathrm{O}_{\mathrm{OZn}}(1.270(8) \AA)$. Moreover, the $\mathrm{Zn}-\mathrm{O}_{\text {OCO bond }}$ distance for the $\mathrm{H}_{2} \mathrm{Br}_{2}$-bdc linker is the same as the $\mathrm{Br}_{2}-\mathrm{bdc}^{2-}$ linker one. In this case a neutral framework is formed (Figure $3 b$ ). There are only 0D cavities (approx. $5 \times 13 \AA$ ) in the structure due to the Br substituents in the terephthalate linker (Figure S2a). The guest accessible volume is $23.4 \%$ according to Mercury calculations [42]. The inner volume is filled with guest molecules of DMA. The $\mathrm{O}$ atom of a DMA molecule is connected with a protonated carboxylate group of the dibromo- terephthalate linkers by a hydrogen bond $(\mathrm{O}$ .. . O distance is $2.843 \AA$ ).

According to single crystal XRD data compound $\left[\mathrm{H}_{2} \mathrm{~N}\left(\mathrm{CH}_{3}\right)_{2}\right]\left[\mathrm{LiZn}_{2}(\mathrm{ndc})_{3}\right] \cdot \mathrm{CH}_{3} \mathrm{CN}$ (3) crystallizes in the monoclinic space group $C 2 / c$. In this structure the starting $\left\{\mathrm{Li}_{2} \mathrm{Zn}_{2}\right\}$ core fragments into dinuclear $\{\mathrm{LiZn}\}$ blocks. In these blocks cations are connected by two bridging naphthalenedicarboxylic linker carboxylates. $\{\mathrm{LiZn}\}$ blocks engage individual $\mathrm{Zn}^{2+}$ cations from the reaction mixture and form trinuclear secondary building units $\left\{\mathrm{LiZn}_{2}\right\}$. These SBUs bind with each other using pairs of bringing carboxylates to form chains along the $c$ axis (Figure 4a). Thus all cations in the structure are in a tetrahedral 
environment of four $\mathrm{O}$ donors from the linkers. $\mathrm{Zn}-\mathrm{O}_{\mathrm{OCO}}$ bond distances values range from 1.922(2) to 2.001(2) $\AA, \mathrm{Li}-\mathrm{O}_{\mathrm{OCO}}$ bond distances vary from 1.890(5) to 1.907(5) $\AA$. Each $\mathrm{SBU}\left\{\mathrm{LiZn}_{2}\right\}$ is connected with eight naphthalenedicarboxylic linkers, which are directed in pairs in four sides to build a negatively charged 3D framework with square cavities (Figure $4 \mathrm{~b}$ ). There are only 0D cavities with aperture $7 \times 7 \AA$ in the structure due to the bulky naphthalene moieties of the linker (Figure S2b). Guest accessible volume is $15.8 \%$ according to Mercury calculations and cavities are filled with dimethylammonium ions and acetonitrile guest molecules [42].

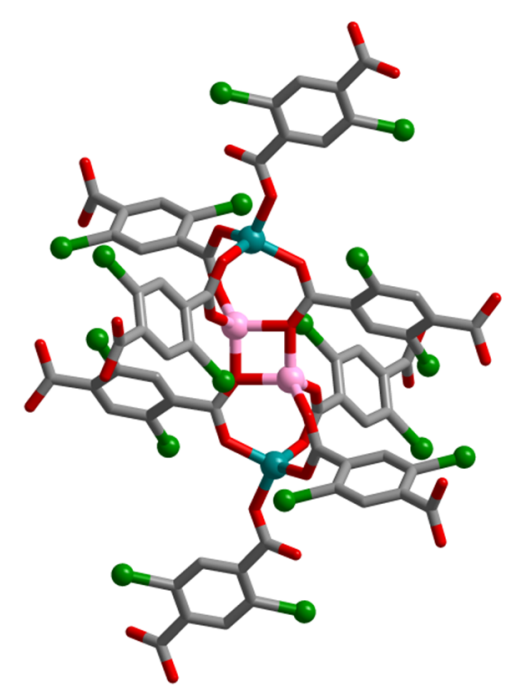

(a)

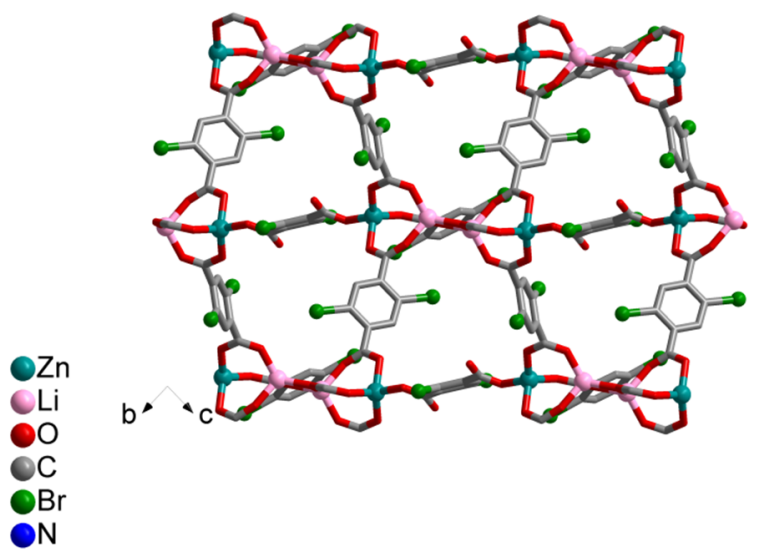

(b)

Figure 3. (a) SBU in compound 2; (b) Structure view of 2 along $a$ axis.

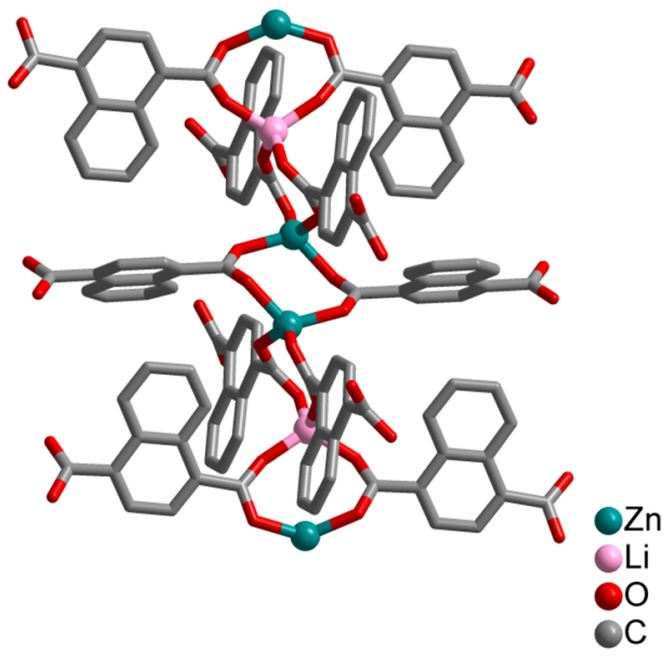

(a)

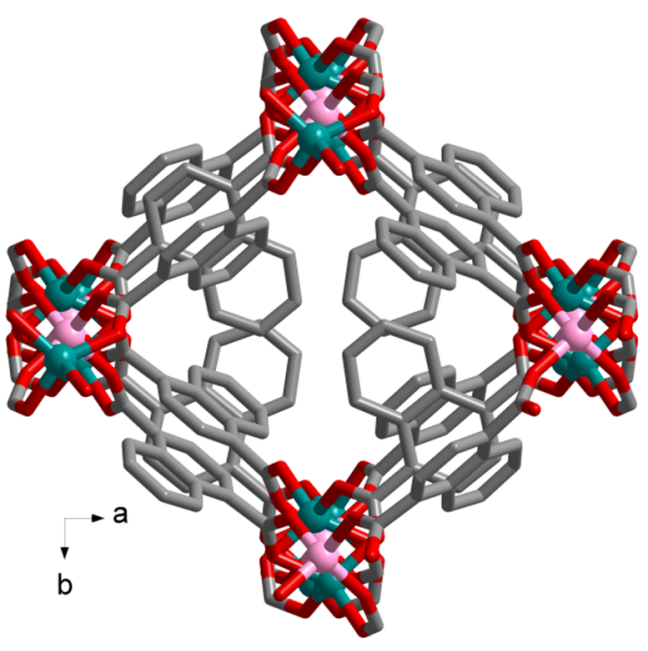

(b)

Figure 4. (a) Chains in compound 3; (b) Structure view of 3 along $c$ axis.

According to single crystal XRD data compound $\left[\left\{\mathrm{Li}_{2} \mathrm{Zn}_{2}(\mathrm{dmf})(\mathrm{py})_{2}\right\}\left\{\mathrm{LiZn}(\mathrm{dmf})_{2}\right\}_{2}\right.$ $\left.\left(\mathrm{NO}_{2} \text {-bdc }\right)_{6}\right] \cdot 5 \mathrm{DMF}(4)$ crystallizes in the triclinic space group $P-1$. There are two types of nodes in this structure: tetranuclear $\left\{\mathrm{Li}_{2} \mathrm{Zn}_{2}\right\}$ and dinuclear $\{\mathrm{LiZn}\}$ cores. Tetranuclear cores conserve the structure of the starting complex and even coordinated pyridine as a terminal ligand (Figure 5a). Pivalate moieties are replaced with nitroterephthalate ones. Both $\mathrm{Zn}^{2+}$ cations are in a square-pyramid environment of three $\mathrm{O}$ donors from carboxylates, one $\mathrm{O}$ donor from $\mathrm{DMF}$ and one $\mathrm{N}$ donor from pyridine. $\mathrm{Zn}-\mathrm{O}_{\mathrm{OCO}}$ bond distances values range from $1.943(3)$ to $2.008(2) \AA, \mathrm{Zn}-\mathrm{O}_{\mathrm{dmf}}$ bond distance is $2.303(5) \AA, \mathrm{Zn}-\mathrm{N}_{\text {py }}$ bond 
distance is $2.303(5) \AA$, which is slightly longer than in the starting complex. $\mathrm{Li}^{+}$cations are in a tetrahedral environment of four $\mathrm{O}$ donors, $\mathrm{Li}-\mathrm{O}_{\mathrm{OCO}}$ bond distances are from $1.865(6)$ to $1.955(6) \AA$, which is slightly shorter than in the starting complex. Almost square angles $\mathrm{O}_{\mathrm{OCO}}-\mathrm{Li}-\mathrm{O}_{\mathrm{OCO}}$ and $\mathrm{Li}-\mathrm{O}_{\mathrm{OCO}}-\mathrm{Li}$ conserve their values of 94.0(2) and 86.0(2) deg., respectively. Each $\left[\mathrm{Li}_{2} \mathrm{Zn}_{2}(\mathrm{py})_{2}(\mathrm{OOCR})_{6}\right]$ node is connected by six nitroterephthalate linkers. Dinuclear $\{\mathrm{LiZn}\}$ blocks consist of $\mathrm{Li}^{+}$and $\mathrm{Zn}^{2+}$ cations partly occupying the same positions (with a population of 0.5 , Figure $5 \mathrm{~b}$ ). Both cations are in a tetrahedral environment of four $\mathrm{O}$ donors, three from carboxylates and one from DMF. $\mathrm{Zn}-\mathrm{O}_{\mathrm{OCO}}$ bond distances values range from 1.915(3) to $1.925(2) \AA, \mathrm{Zn}-\mathrm{O}_{\mathrm{dmf}}$ bond distance is $1.971(3) \AA, \mathrm{Li}-\mathrm{O}_{\mathrm{OCO}}$ bond distances range from 1.892(3) to $1.910(3) \AA$, $\mathrm{Li}-\mathrm{O}_{\mathrm{dmf}}$ bond distance is $1.967(3) \AA$. $\{\mathrm{LiZn}\}$ cores are connected with three nitroterephthalate linkers. Each $\left\{\mathrm{Li}_{2} \mathrm{Zn}_{2}\right\}$ core binds to six $\{\mathrm{LiZn}\}$ cores using six nitroterephthalates, while the $\{\mathrm{LiZn}\}$ core is connected with three $\left\{\mathrm{Li}_{2} \mathrm{Zn}_{2}\right\}$ cores (Figure $\left.5 \mathrm{c}\right)$. Thus a layer with a biporous structure $(6 \times 6 \AA$ and $8 \times 4 \AA)$ is formed. These layers have $\mathrm{AB}$ packing (Figure $5 \mathrm{~d}$ ) and form a 3D framework with a tortuous system of channels (Figure S2c). Guest accessible volume is $25.6 \%$ according to Mercury calculations and the cavities are filled with DMF guest molecules [42].

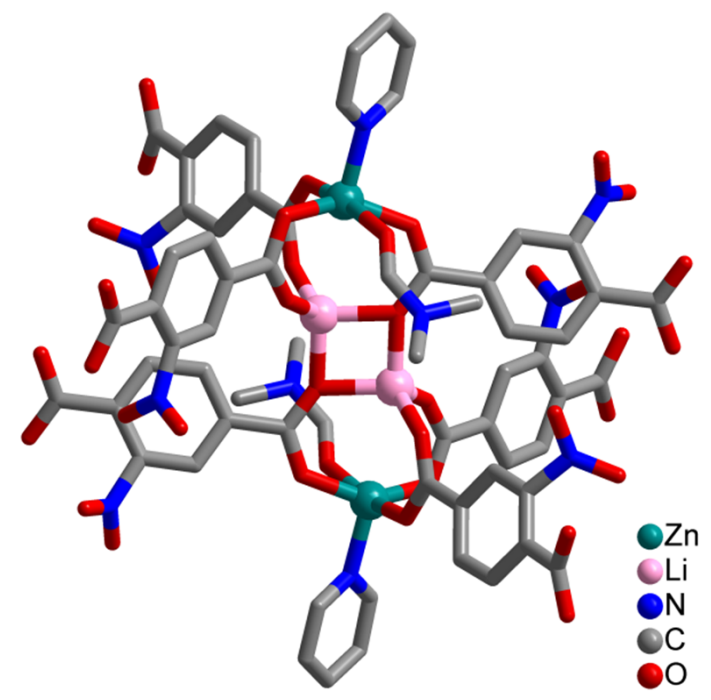

(a)

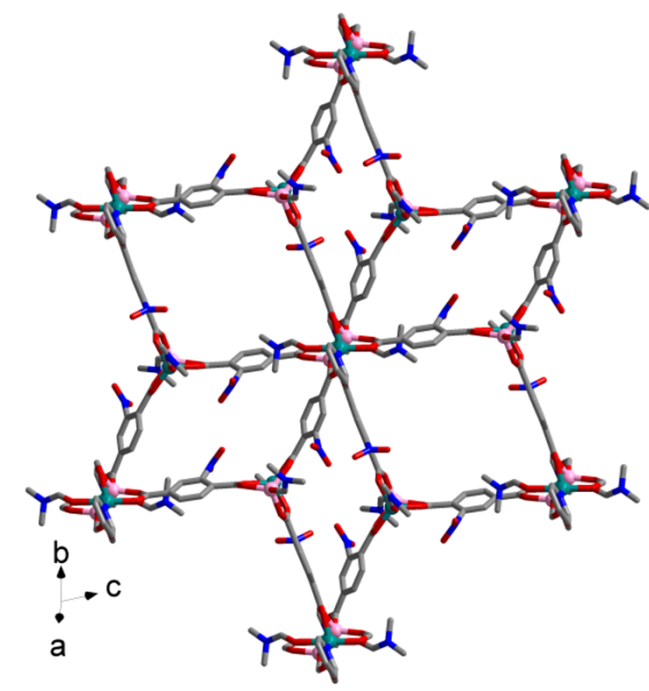

(c)

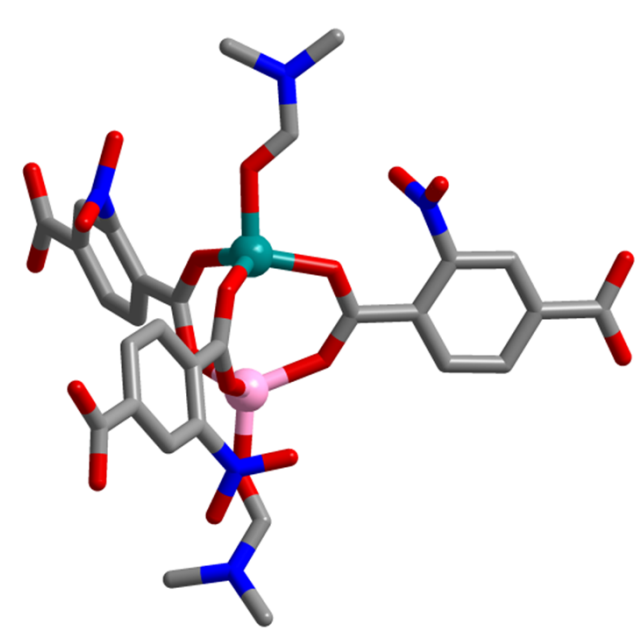

(b)

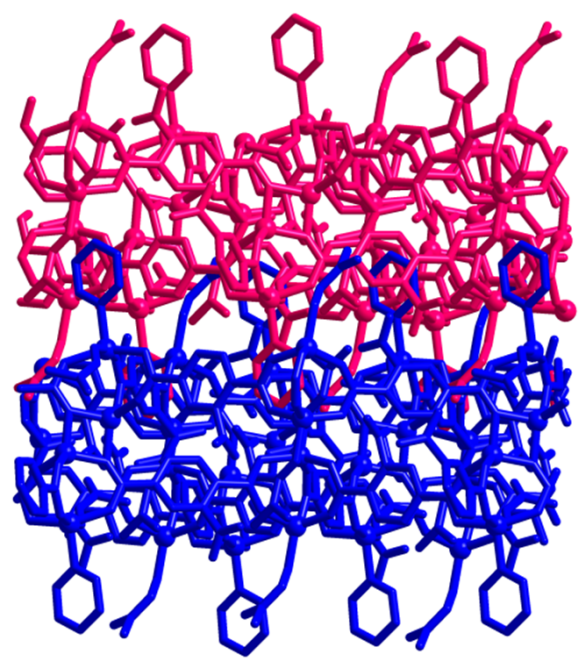

(d)

Figure 5. (a) Tetranuclear SBU in compound 4; (b) Dinuclear SBU in compound 4; (c) Connectivity of tetranuclear and dinuclear SBUs in 4; (d) AB packing of layers in 4, layers shown in different colors. 
Compounds 1, 2 and 3 were obtained as individual products in good yields ( $>50 \%)$. The phase purity of the bulk samples was shown by powder XRD analysis (Figure 6). Chemical composition and structure were confirmed by elemental analysis and IR spectroscopy (Figures S3-S5). The stretching vibration bands of carboxyl groups of the organic linkers and aldehyde group of DMF are located around $1600 \mathrm{~cm}^{-1}$. O-H, C-H stretching vibration bands of ligands and DMF are located from 3600 to $2900 \mathrm{~cm}^{-1}$. C-H bending vibration bands of ligands and DMF are located in the $1450-1350 \mathrm{~cm}^{-1}$ region.

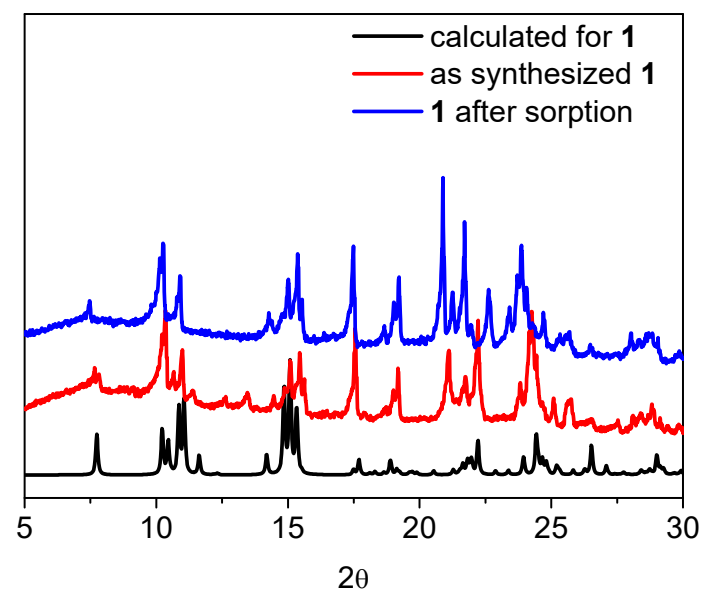

(a)

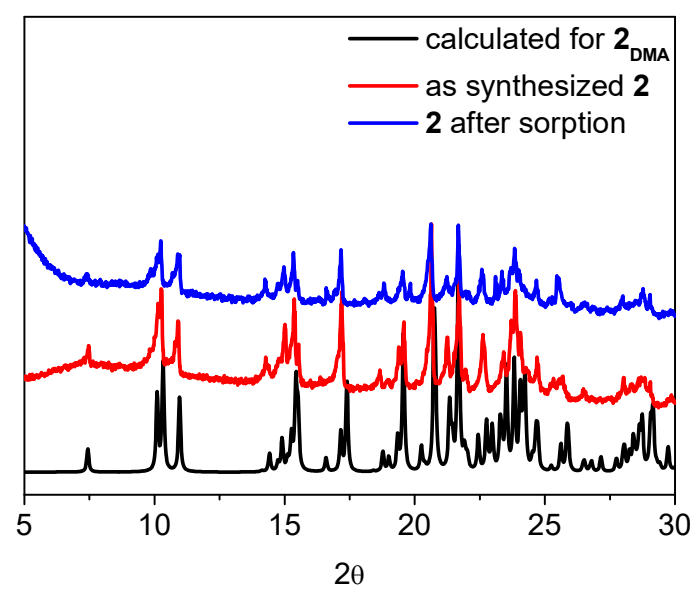

(b)

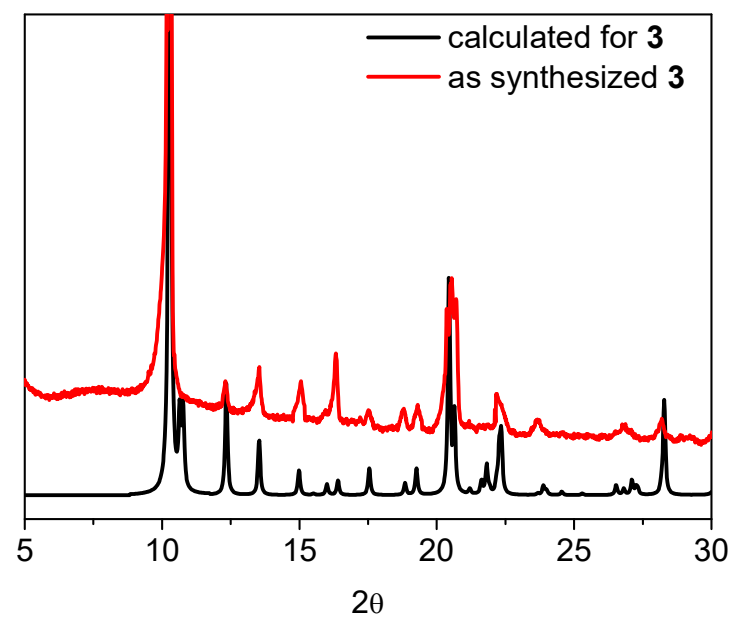

(c)

Figure 6. (a) PXRD patterns of as synthesized 1 and after sorption of $\mathrm{N}_{2}$ and $\mathrm{CO}_{2}$ in comparison with calculated one; (b) PXRD patterns of as synthesized 2 and after sorption of $\mathrm{N}_{2}$ and $\mathrm{CO}_{2}$ in comparison with calculated one; (c) PXRD patterns of as synthesized 3 in comparison with calculated one.

For the safe evacuation of the guest molecules compounds were activated by soaking in acetone for two days and application of further evacuation and dynamic vacuum at $80^{\circ} \mathrm{C}$. To determine the texture characteristics and porosity of the obtained materials we recorded the $\mathrm{N}_{2}$ and $\mathrm{CO}_{2}$ adsorption isotherms at $77 \mathrm{~K}$ and $195 \mathrm{~K}$, respectively. The experiments have shown very low $\mathrm{N}_{2}$ sorption capacity for both compounds, demonstrating almost no porosity (Figure 7a). Meanwhile the PXRD patterns of the activated compounds (Figure 6) have shown the retention of the frameworks initial structure. Thus we additionally investigated the sorption of $\mathrm{CO}_{2}$, which has a smaller kinetic diameter comparing to the $\mathrm{N}_{2}$ molecule (Figure $7 \mathrm{~b}$ ). The BET surface area values calculated from these data are 61 and $10 \mathrm{~m}^{2} / \mathrm{g}$ for $\mathbf{1}$ and $\mathbf{2}$, respectively. 


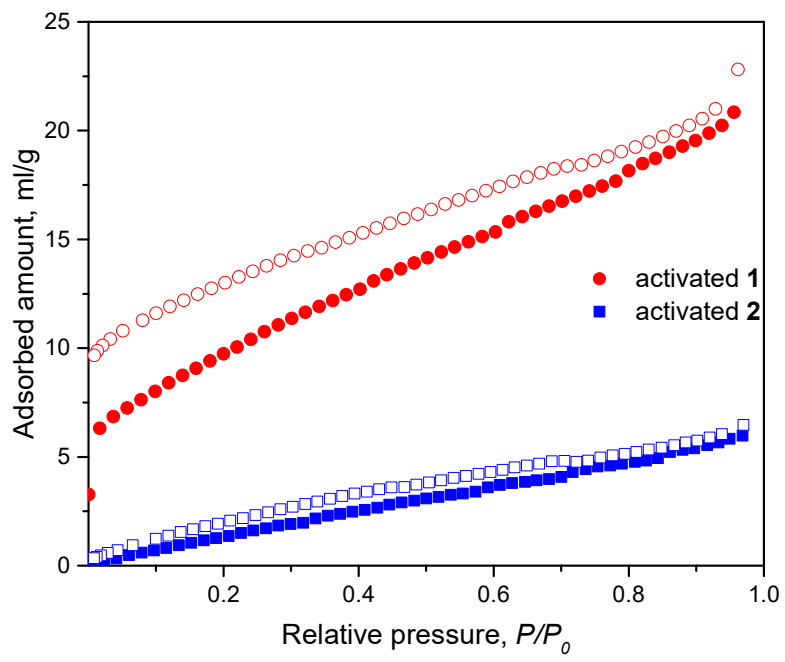

(a)

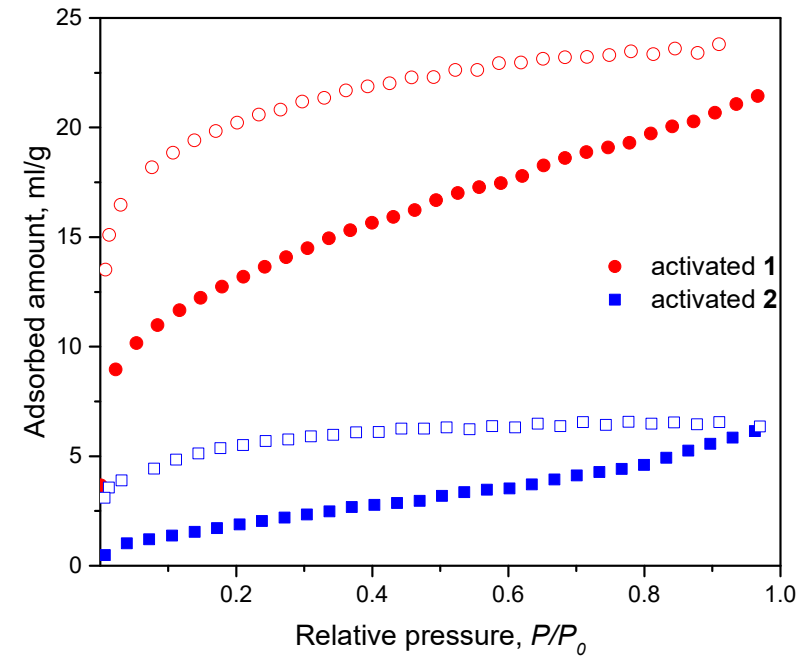

(b)

Figure 7. (a) $\mathrm{N}_{2}$ sorption isotherms at $77 \mathrm{~K}$ for activated $\mathbf{1}$ and 2; (b) $\mathrm{CO}_{2}$ sorption isotherms at $195 \mathrm{~K}$ for activated $\mathbf{1}$ and 2. Adsorption curves is shown with filled symbols, desorption-empty symbols.

For compounds $\mathbf{1}$ and $\mathbf{2}$ solid state luminescence of as synthesized and inclusion compounds with benzene and nitrobenzene were investigated (Figure 8). To obtain inclusion compounds samples of as synthesized compounds were previously activated to remove guest solvent molecules and then immersed in the corresponding solvent (benzene or nitrobenzene). Both $\mathrm{Zn}^{\mathrm{II}}$ and $\mathrm{Li}^{\mathrm{I}}$ complexes are redox inactive and not known to interfere with the ligand-centered luminescence [43]. Compounds $\mathbf{1}$ and $\mathbf{2}$ have one broad band of emission with maximum at about $450 \mathrm{~nm}\left(\lambda_{\mathrm{ex}}=380 \mathrm{~nm}\right)$, which could be assigned to the intraligand $\pi^{*} \rightarrow \pi$ transition in organic linkers. In the case of compound $\mathbf{1}$, the maximum is at $445 \mathrm{~nm}$, which corresponds to the literature data for MOFs based on terephthalates [44,45]. For compound 2 emission maximum $(460 \mathrm{~nm})$ shifts to a longer wavelength region which corresponds to changes in the electronic structure of the ring when bromine is added as substituents. The soaking of compounds $\mathbf{1}$ in benzene and nitrobenzene results in changing of luminescence intensity and quantum yields (QY). For the as synthesized compound $1 \mathrm{QY}$ is $41 \%$. After immersing crystalline powder in benzene the QY of inclusion compounds decreases to $19.5 \%$. This could be explained by a decrease in the rigidity of the framework due to the small amount of included benzene. This, in turn, significantly increases the probability of vibrational nonradiative transitions in the ligand and leads to a decrease in the quantum yield. Inclusion of nitrobenzene in framework 1 results in full quenching of the emission. In the case of compound 2 the QY for an as synthesized sample and an inclusion compound are almost the same: $6.8 \%$ for $2,5.3 \%$ for benzene@2, and 4.7\% for nitrobenzene@2. This may indicate that only a few molecules of benzene and nitrobenzene enter the inner volume of the framework.

Analysis of obtained samples by TGA allowed us to determine the quantity of benzene and nitrobenzene molecules located in the inner volume of frameworks $\mathbf{1}$ and $\mathbf{2}$ (Figure 9). For all samples of compound 1 the mass loss starts at about $100{ }^{\circ} \mathrm{C}$. A second step for as synthesized 2 and its inclusion compounds starts at about $250{ }^{\circ} \mathrm{C}$. Mass loss between these temperatures is attributed to the removal of solvent molecules from the inner volume. For as synthesized 1 the mass loss is $6.5 \%$ which corresponds to 0.9 molecules of DMF. For benzene@1 the mass loss is 5.0\% which corresponds to 0.6 molecules of benzene and for nitrobenzene@1 the mass loss is 8.0\% (0.6 molecules of nitrobenzene). As for compound 2 it is far more stable than compound $\mathbf{1}$. The first mass loss starts at about $250{ }^{\circ} \mathrm{C}$, the second at $325{ }^{\circ} \mathrm{C}$ for all samples. For as synthesized 2 the mass loss is $3.5 \%$ which corresponds to 0.7 molecules of DMF. For benzene@2 and nitrobenzene@2 the mass loss is 3.5\% (0.7 molecules of benzene) and $6.0 \%$ (0.8 molecules of nitrobenzene), respectively. 


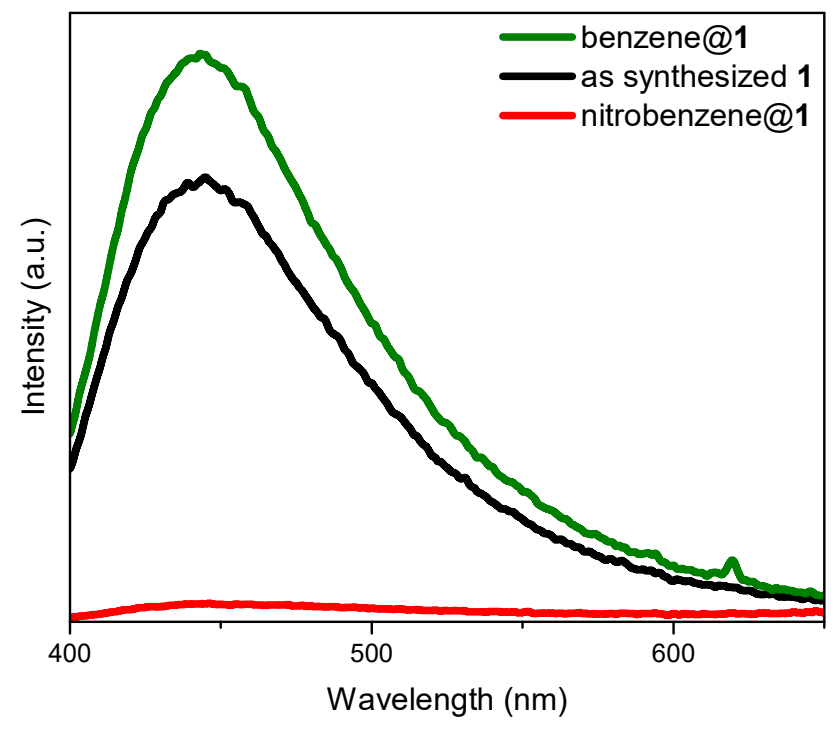

(a)

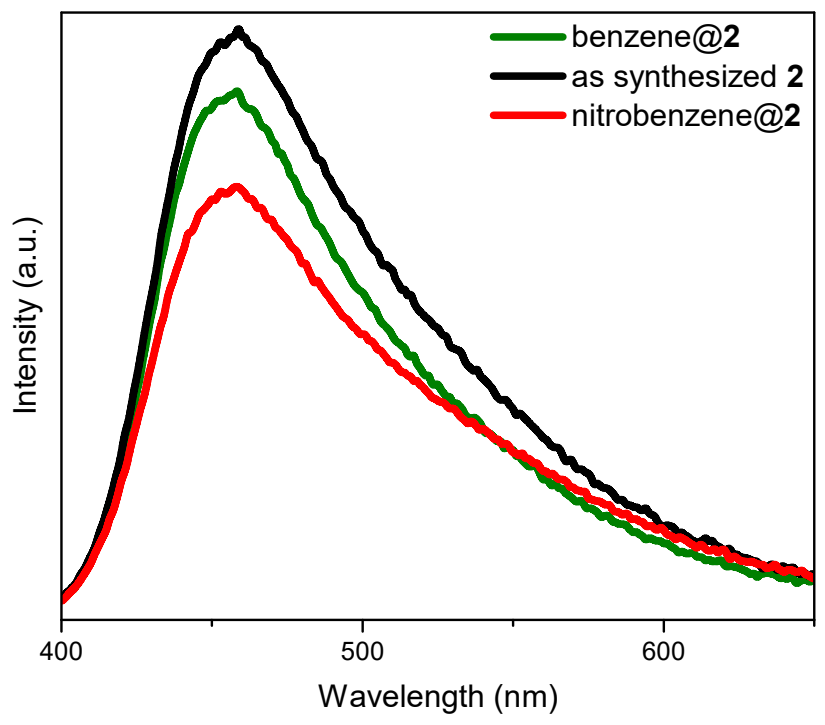

(b)

Figure 8. (a) Emission spectra of as synthesized 1, soaked in benzene and nitrobenzene, $\lambda_{\mathrm{ex}}=380 \mathrm{~nm}$; (b) Emission spectra of as synthesized 2 , soaked in benzene and nitrobenzene, $\lambda_{\mathrm{ex}}=380 \mathrm{~nm}$.

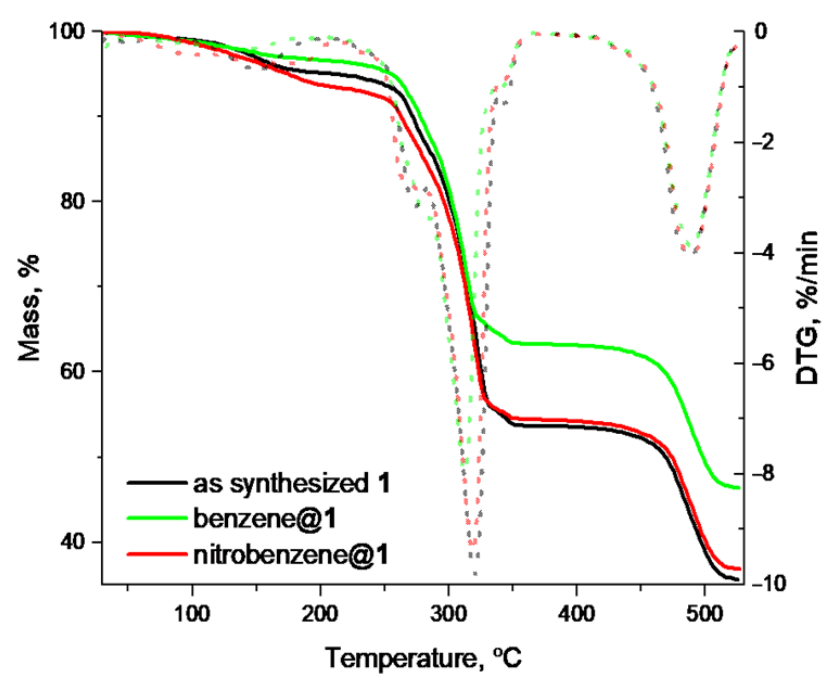

(a)

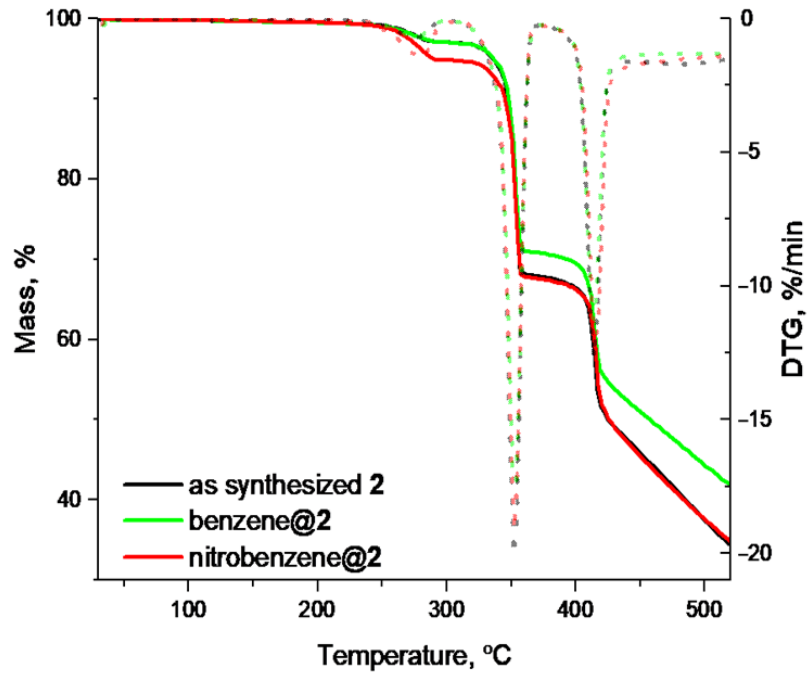

(b)

Figure 9. (a) TGA of as synthesized 1, soaked in benzene and nitrobenzene; (b) TGA of as synthesized 2, soaked in benzene and nitrobenzene.

\section{Discussion}

Analysis of the obtained structures and synthesis conditions shows that terephthalic and dibromoterephthalic acids act almost the same as linkers. Despite the different unit cell parameters and space group compounds $\mathbf{1}$ and $\mathbf{2}$ are isoreticular (Figures $2 \mathrm{~b}$ and $3 \mathrm{~b}$ ). The starting tetranuclear core $\left\{\mathrm{Li}_{2} \mathrm{Zn}_{2}\right\}$ fully retains its structure. The main difference in structures is a presence of dimethylammonium cation in the structure of compound $\mathbf{1}$.

We previously demonstrated that under a lower temperature of $100{ }^{\circ} \mathrm{C}$ it was only possible to obtain $\left\{\mathrm{Li}_{2} \mathrm{Zn}_{2}\right\}-\mathrm{MOF}\left[\mathrm{Li}_{2} \mathrm{Zn}_{2}(\mathrm{bdc})_{3}(\mathrm{bpy})\right] \cdot 3 \mathrm{DMF} \cdot \mathrm{CH}_{3} \mathrm{CN} \cdot \mathrm{H}_{2} \mathrm{O}$ based on terephthalic acid using an additional neutral ligand, 4,4'-bipyridine [41]. This fact was confirmed in the next compound $\left[\mathrm{Li}_{2} \mathrm{Zn}_{2} \text { (bpdc) }\right)_{3}$ (dabco)] $9 \mathrm{DMF} \cdot 4 \mathrm{H}_{2} \mathrm{O}$ where diazabicyclo[2.2.2]octane 
(dabco) was used as a neutral ligand and biphenyldicarboxylic acid was used instead of terephthalic acid [41]. In other cases when dabco or any other coligand was not used in the reaction mixture, only dinuclear $\{\mathrm{ZnLi}\}-\mathrm{MOF}$ were obtained [46]. In this study we demonstrate that increasing the reaction temperature up $130^{\circ} \mathrm{C}$ allowed us to obtain $3 \mathrm{D}$ frameworks with preserved $\left\{\mathrm{Li}_{2} \mathrm{Zn}_{2}\right\}$ cores using only one type of ligands.

In the reaction of pivalate complex $\left[\mathrm{Li}_{2} \mathrm{Zn}_{2}(\mathrm{piv})_{6}(\mathrm{py})_{2}\right]$ with naphthalenedicarboxylic acid, only structures with dinuclear $\{\mathrm{LiZn}\}$ cores were obtained. This could be explained by steric hindrance caused by the massive additional benzene ring substituent during structure formation. Structures containing $\{\mathrm{LiZn}\}$ blocks were previously obtained using naphthalenedicarboxylic, nitroterephthalic, trimesic and biphenyldicarboxylic acids when preservation of the tetranuclear core is difficult [47-50].

In the case of compound 4 one of the rarest examples of simultaneous presence of two different heterometallic cores in one structure is observed.

Investigation of the luminescence properties demonstrated that framework $\mathbf{1}$ is able to let in nitrobenzene molecules which quench the luminescence. At the same time, framework 2 contains only $0 \mathrm{D}$ cavities, which are difficult to penetrate. This fact results in very small changes of the QY and an almost complete absence of luminescence quenching by nitrobenzene.

\section{Materials and Methods}

All chemicals (terephthalic acid, Sigma-Aldrich, Germany, $\geq 98 \%$ ), 2,5-dibromoterephthalic acid (TCI, Japan, $>98.0 \%$ ), 1,4-naphthalenedicarboxylic acid (TCI, $>95.0 \%$ ), nitroterephthalic acid (Sigma-Aldrich, Switzerland, $\geq 99 \%$ ), N,N-dimethylformamide ("Reactiv", Russia, >99\%), N,N-dimethylacetamide ("Vecton", Russia, 99.95\%), $\mathrm{CH}_{3} \mathrm{CN}$ ("Cryochrom", Russia, 99.95\%)) were of reagent grade and used as received without further purification. The complex $\left.\left[\mathrm{Li}_{2} \mathrm{Zn}_{2} \text { (piv) }\right)_{6}(\mathrm{py})_{2}\right]$ was obtained according to a previously published procedure [41]. FTIR spectra were recorded in the range $4000-400 \mathrm{~cm}^{-1}$ for the $\mathrm{KBr}$ pelleted samples on a VERTEX 80 spectrometer. The powder X-ray diffraction (PXRD) data were collected with $\mathrm{Cu}-\mathrm{K} \alpha$ radiation on a XRD $7000 \mathrm{~S}$ powder diffractometer (Shimadzu). The elemental analyses on C, H and N were performed on a Vario Micro-Cube analyzer. The thermogravimetric analysis was carried out in He atmosphere on a TG 209 F1 thermoanalyzer NETZSCH with a heating rate of $10 \mathrm{deg} / \mathrm{min}$. An analysis of the porous structure was performed by a nitrogen adsorption at $77 \mathrm{~K}$ and carbon dioxide at $195 \mathrm{~K}$ using Quantochrome's AutosorbiQ system. The emission spectra of solid samples were recorded on a Cary Eclipse Varian fluorescence spectrophotometer at room temperature under $\lambda_{\mathrm{Ex}}=380 \mathrm{~nm}$.

\subsection{Synthesis}

\subsubsection{Synthesis of $\left[\mathrm{H}_{2} \mathrm{~N}\left(\mathrm{CH}_{3}\right)_{2}\right]_{2}\left[\mathrm{Li}_{2} \mathrm{Zn}_{2}(\mathrm{bdc})_{4}\right] \cdot \mathrm{CH}_{3} \mathrm{CN} \cdot \mathrm{DMF}$ (1)}

A mixture of complex [ $\left.\mathrm{Li}_{2} \mathrm{Zn}_{2}(\mathrm{piv})_{6}(\mathrm{py})_{2}\right](0.025 \mathrm{~g}, 0.027 \mathrm{mmol})$, obtained according to a previously published procedure [41], terephthalic acid $\left(\mathrm{H}_{2} \mathrm{bdc}, 0.030 \mathrm{~g}, 0.181 \mathrm{mmol}\right), \mathrm{N}, \mathrm{N}$ dimethylformamide (DMF, $1 \mathrm{~mL})$ and acetonitrile $\left(\mathrm{CH}_{3} \mathrm{CN}, 4 \mathrm{~mL}\right)$ was heated in a closed vial at $130^{\circ} \mathrm{C}$ for 2 days. The colorless block crystal was used for single crystal XRD analysis. Obtained crystals were collected and washed with DMF $(3 \times 1 \mathrm{~mL})$ and dried at air. Yield: $0.015 \mathrm{~g}(55 \%)$. Elemental analysis calcd (\%) for $\left[\mathrm{H}_{2} \mathrm{~N}\left(\mathrm{CH}_{3}\right)_{2}\right]_{2}\left[\mathrm{Li}_{2} \mathrm{Zn}_{2}(\mathrm{bdc})_{4}\right] \cdot \mathrm{CH}_{3} \mathrm{CN} \cdot \mathrm{DMF}$, $\mathrm{C}_{41} \mathrm{H}_{42} \mathrm{Li}_{2} \mathrm{~N}_{4} \mathrm{O}_{17} \mathrm{Zn}_{2}$ : C 48.88, H 4.20, N 5.56; found: C 48.97, H 4.56, N 5.51. IR (KBr, cm $\left.{ }^{-1}\right)$ : $3425 \mathrm{~m}, 3065 \mathrm{w}, 2663 \mathrm{w}, 2544 \mathrm{w}, 1965 \mathrm{w}, 1682 \mathrm{~s}, 1597 \mathrm{~s}, 1504 \mathrm{~s}, 1387 \mathrm{~s}, 1294 \mathrm{~s}, 1136 \mathrm{w}, 1113 \mathrm{w}$, $1018 \mathrm{~m}, 985 \mathrm{w}, 936 \mathrm{~m}, 881 \mathrm{~m}, 825 \mathrm{~s}, 750 \mathrm{~s}, 530 \mathrm{~s}, 472 \mathrm{w}, 415 \mathrm{w}$.

\subsubsection{Synthesis of $\left[\mathrm{Li}_{2} \mathrm{Zn}_{2}\left(\mathrm{H}_{2} \mathrm{Br}_{2}\right.\right.$-bdc $\left.)\left(\mathrm{Br}_{2} \text {-bdc }\right)_{3}\right] \cdot 2 \mathrm{DMF}$ (2)}

Compound 2 was synthesized according to procedure used for 1 . A mixture of complex [ $\mathrm{Li}_{2} \mathrm{Zn}_{2}$ (piv) $\left.)_{6}(\mathrm{py})_{2}\right](0.025 \mathrm{~g}, 0.027 \mathrm{mmol}), 2,5$-dibromoterephthalic acid $\left(\mathrm{H}_{2} \mathrm{Br}_{2-}\right.$ bdc, $0.057 \mathrm{~g}, 0.176 \mathrm{mmol}), \mathrm{N}, \mathrm{N}$-dimethylformamide (DMF, $1 \mathrm{~mL})$ and acetonitrile $\left(\mathrm{CH}_{3} \mathrm{CN}\right.$, $4 \mathrm{~mL}$ ) was heated in a closed vial at $130^{\circ} \mathrm{C}$ for 2 days. Obtained colorless crystals were 
collected and washed with DMF $(3 \times 1 \mathrm{~mL})$ and dried in air. Yield: $0.034 \mathrm{~g}(78 \%)$. For further syntheses DMF was used instead of DMA to increase the yield. Chemical composition was obtained using IR spectra, TG and elemental analyses. Elemental analysis calcd (\%) for $\left[\mathrm{Li}_{2} \mathrm{Zn}_{2}\left(\mathrm{H}_{2} \mathrm{Br}_{2}-\mathrm{bdc}\right)\left(\mathrm{Br}_{2}-\mathrm{bdc}\right)_{3}\right] \cdot 2 \mathrm{DMF}, \mathrm{C}_{38} \mathrm{H}_{24} \mathrm{Br}_{8} \mathrm{Li}_{2} \mathrm{~N}_{2} \mathrm{O}_{18} \mathrm{Zn}_{2}$ : C 28.88, H 1.53, N 1.77; found: C 28.50, H 1.86, N 1.73. IR (KBr, cm $\left.{ }^{-1}\right)$ : $3352 \mathrm{~m}, 3161 \mathrm{~s}, 3086 \mathrm{w}, 1641 \mathrm{~s}, 1473 \mathrm{~m}, 1360$ s, 1313 s, 1269 w, 1151 m, 1103 w, 1059 s, 936 w, 907 m, 893 m, 827 s, 789 s, 644 m, 555 s, 496 $\mathrm{w}, 432 \mathrm{~m}$. Due to the insufficient quality of the crystals obtained for single crystal XRD analysis colorless plate crystals synthesized using DMA instead of DMF were used (2 $\mathbf{D M A}_{\mathbf{D A}}$ ).

\subsubsection{Synthesis of $\left[\mathrm{H}_{2} \mathrm{~N}\left(\mathrm{CH}_{3}\right)_{2}\right]\left[\mathrm{LiZn}_{2}\right.$ (ndc) 3$] \cdot \mathrm{CH}_{3} \mathrm{CN}$ (3)}

Compound 3 was synthesized according to procedure used for 1 using 1,4-naphthalenedicarboxylic acid $\left(\mathrm{H}_{2}\right.$ ndc, $\left.0.038 \mathrm{~g}, 0.176 \mathrm{mmol}\right)$ as a ligand. The colorless block crystal was used for single crystal XRD analysis. Obtained crystals were collected and washed with DMF $(3 \times 1 \mathrm{~mL})$ and dried in air. Yield: $0.014 \mathrm{~g}(60 \%)$. Elemental analysis calcd (\%) for $\left.\left[\mathrm{H}_{2} \mathrm{~N}\left(\mathrm{CH}_{3}\right)_{2}\right]\left[\mathrm{LiZn}_{2} \text { (ndc) }\right)_{3}\right] \cdot \mathrm{CH}_{3} \mathrm{CN}, \mathrm{C}_{40} \mathrm{H}_{29} \mathrm{LiN}_{2} \mathrm{O}_{12} \mathrm{Zn}_{2}$ : C 55.39, H 3.37, N 3.23; found: C 55.18, H 3.32, N 3.38. IR (KBr, cm $\left.{ }^{-1}\right)$ : $3331 \mathrm{w}, 3055 \mathrm{w}, 2926 \mathrm{w}, 1625 \mathrm{~s}, 1504 \mathrm{~m}, 1367 \mathrm{~s}$, $1220 \mathrm{~m}, 1151 \mathrm{w}, 1074 \mathrm{~m}, 1116 \mathrm{~s}, 878 \mathrm{w}, 827 \mathrm{~s}, 748 \mathrm{~s}, 644 \mathrm{~m}, 530 \mathrm{~s}, 409 \mathrm{~m}$.

\subsubsection{Synthesis of $\left[\left\{\mathrm{Li}_{2} \mathrm{Zn}_{2}(\mathrm{dmf})(\mathrm{py})_{2}\right\}\left\{\mathrm{LiZn}(\mathrm{dmf})_{2}\right\}_{2}\left(\mathrm{NO}_{2}-\mathrm{bdc}\right)_{6}\right] \cdot 5 \mathrm{DMF}$ (4)}

Compound 4 was synthesized according to procedure used for $\mathbf{1}$ using nitroterephthalic acid $\left(\mathrm{H}_{2} \mathrm{NO}_{2}\right.$-bdc, $\left.0.031 \mathrm{~g}, 0.149 \mathrm{mmol}\right)$ as a ligand and at temperature of $100{ }^{\circ} \mathrm{C}$. The yellow plate crystal was used for single crystal XRD analysis.

\subsection{X-Ray Crystallography}

Diffraction data for single crystals 1, 3 and 4 were obtained on an automated Agilent Xcalibur diffractometer equipped with an area AtlasS2 detector (graphite monochromator, $\lambda(\operatorname{MoK} \alpha)=0.71073 \AA$, $\omega$-scans with a step of $\left.0.5^{\circ}\right)$. Integration, absorption correction, and determination of unit cell parameters were performed using the CrysAlisPro program package [51]. Diffraction data for single crystals 2 DMA were collected on the 'Belok' beamline $\left(\lambda=0.79313 \AA, \varphi\right.$-scans with a step of $\left.1.0^{\circ}\right)$ of the National Research Center 'Kurchatov Institute' (Moscow, Russian Federation) using a Rayonix SX165 CCD detector. The data were indexed, integrated and scaled, absorption correction was applied using the XDS program package [52]. The structures were solved by dual space algorithm (SHELXT [53]) and refined by the full-matrix least squares technique (SHELXL [54]) in the anisotropic approximation (except hydrogen atoms). Positions of hydrogen atoms of organic ligands were calculated geometrically and refined in the riding model. The structures 3 and 4 contain large void volumes occupied with highly disordered solvent guest molecules (DMF and $\mathrm{CH}_{3} \mathrm{CN}$ ), which could not be refined as a set of discrete atoms. The final compositions of compounds 3 and 4 were defined according to PLATON/SQUEEZE procedure [55] (180 e- in $823 \AA^{3}$ for 3, $206 \mathrm{e}-$ in $836 \AA^{3}$ for 4) and the data of elemental $(C, H, N)$ analysis. The crystallographic data and details of the structure refinements are summarized in Table 1. CCDC 2045318-2045321 contain the supplementary crystallographic data for this paper. These data can be obtained free of charge from The Cambridge Crystallographic Data Center at http:/ / www.ccdc.cam.ac.uk/data_request/cif. 
Table 1. Crystal data and structure refinement for compounds 1-4.

\begin{tabular}{|c|c|c|c|c|}
\hline Identification Code & 1 & ${ }^{2}$ DMA & 3 & 4 \\
\hline Empirical formula & $\mathrm{C}_{41} \mathrm{H}_{42} \mathrm{Li}_{2} \mathrm{~N}_{4} \mathrm{O}_{17} \mathrm{Zn}_{2}$ & $\mathrm{C}_{40} \mathrm{H}_{28} \mathrm{Br}_{8} \mathrm{Li}_{2} \mathrm{~N}_{2} \mathrm{O}_{18} \mathrm{Zn}_{2}$ & $\mathrm{C}_{40} \mathrm{H}_{29} \mathrm{LiN}_{2} \mathrm{O}_{12} \mathrm{Zn}_{2}$ & $\mathrm{C}_{88} \mathrm{H}_{98} \mathrm{Li}_{4} \mathrm{~N}_{18} \mathrm{O}_{46} \mathrm{Zn}_{4}$ \\
\hline$M, \mathrm{~g} \cdot \mathrm{mol}^{-1}$ & 1007.40 & 1608.54 & 867.33 & 2433.08 \\
\hline$T, \mathrm{~K}$ & $150(2)$ & $100(2)$ & $150(2)$ & $150(2)$ \\
\hline Crystal system & Monoclinic & Triclinic & Monoclinic & Triclinic \\
\hline Space group & $P 2_{1} / n$ & $P-1$ & $\mathrm{C} 2 / \mathrm{c}$ & $P-1$ \\
\hline$a, \AA$ & $9.9681(3)$ & $9.675(5)$ & $15.6794(4)$ & $13.4894(6)$ \\
\hline$b, \AA$ & $15.9931(6)$ & $12.346(3)$ & $13.2596(4)$ & $14.8036(6)$ \\
\hline$c, \AA$ & $16.2939(6)$ & $12.523(2)$ & 19.9294(6) & $17.0021(6)$ \\
\hline$\alpha, \operatorname{deg}$ & 90 & $80.897(16)$ & 90 & $64.769(4)$ \\
\hline$\beta, \operatorname{deg}$ & $92.160(3)$ & $71.847(16)$ & 104.551(3) & $73.282(4)$ \\
\hline$\gamma, \operatorname{deg}$ & 90 & $70.278(16)$ & 90 & $86.538(4)$ \\
\hline$V, \AA^{3}$ & 2595.74(16) & $1335.7(8)$ & $4010.5(2)$ & $2933.9(2)$ \\
\hline Z & 2 & 1 & 4 & 1 \\
\hline$D($ calcd $), \mathrm{g} \cdot \mathrm{cm}^{-3}$ & 1.289 & 2.000 & 1.436 & 1.377 \\
\hline$\mu, \mathrm{mm}^{-1}$ & 0.990 & 9.131 & 1.260 & 0.899 \\
\hline$F(000)$ & 1036 & 772 & 1768 & 1252 \\
\hline Crystal size, $\mathrm{mm}$ & $0.29 \times 0.21 \times 0.18$ & $0.10 \times 0.10 \times 0.05$ & $0.32 \times 0.20 \times 0.09$ & $0.34 \times 0.30 \times 0.05$ \\
\hline$\theta$ range for data collection, deg & 2.43-28.51 & $1.9-31.0$ & 2.68-28.74 & 2.37-28.35 \\
\hline Index ranges & $\begin{array}{l}-10 \leq h \leq 12 \\
-20 \leq k \leq 16 \\
-20 \leq l \leq 20\end{array}$ & $\begin{array}{l}-12 \leq h \leq 12 \\
-15 \leq k \leq 15 \\
-16 \leq l \leq 16\end{array}$ & $\begin{array}{l}-14 \leq h \leq 19 \\
-16 \leq k \leq 13 \\
-20 \leq l \leq 26\end{array}$ & $\begin{array}{l}-17 \leq h \leq 18 \\
-13 \leq k \leq 18 \\
-19 \leq l \leq 22\end{array}$ \\
\hline Reflections collected/indep. & $12,7 \overline{93} / \overline{5802}$ & $15,93 \overline{35} / \overline{5956}$ & $10,384 / 4510$ & $26,11 \overline{5} / 12,851$ \\
\hline$R_{\text {int }}$ & 0.0303 & 0.0585 & 0.0120 & 0.0330 \\
\hline Reflections with $I>2 \sigma(I)$ & 4603 & 5265 & 4127 & 9028 \\
\hline GOF on $F^{2}$ & 1.093 & 1.063 & 1.087 & 1.067 \\
\hline Final $R$ indices $[I>2 \sigma(I)]$ & $\begin{array}{r}R_{1}=0.0536 \\
w R_{2}=0.0713\end{array}$ & $\begin{array}{r}R_{1}=0.0624 \\
w R_{2}=0.0683\end{array}$ & $\begin{array}{c}R_{1}=0.0493 \\
w R_{2}=0.0530\end{array}$ & $\begin{array}{r}R_{1}=0.0633 \\
w R_{2}=0.0902\end{array}$ \\
\hline$R$ indices (all data) & $\begin{array}{c}R_{1}=0.1592 \\
w R_{2}=0.1717\end{array}$ & $\begin{array}{r}R_{1}=0.1663 \\
w R_{2}=0.1691\end{array}$ & $\begin{array}{r}R_{1}=0.1358 \\
w R_{2}=0.1383\end{array}$ & $\begin{array}{c}R_{1}=0.1922 \\
w R_{2}=0.2064\end{array}$ \\
\hline Largest diff. peak/hole, $e \cdot \AA^{-3}$ & $0.916 /-0.697$ & $1.288 /-1.267$ & $1.441 /-0.902$ & $0.900 /-0.726$ \\
\hline
\end{tabular}

\section{Conclusions}

By applying a rare but efficient approach to the synthesis of heterometallic metalorganic frameworks we managed to obtain four new compounds: $\left.\mathrm{H}_{2} \mathrm{~N}\left(\mathrm{CH}_{3}\right)_{2}\right]_{2}\left[\mathrm{Li}_{2} \mathrm{Zn}_{2}\right.$ (bdc) $\left.)_{4}\right] \cdot \mathrm{CH}_{3} \mathrm{CN} \cdot \mathrm{DMF}(\mathbf{1}),\left[\mathrm{Li}_{2} \mathrm{Zn}_{2}\left(\mathrm{H}_{2} \mathrm{Br}_{2}\right.\right.$-bdc) $\left.\left(\mathrm{Br}_{2} \text {-bdc) }\right)_{3}\right] \cdot 2 \mathrm{DMF}(\mathbf{2}),\left[\mathrm{H}_{2} \mathrm{~N}\left(\mathrm{CH}_{3}\right)_{2}\right]\left[\mathrm{LiZn}_{2}\right.$ $\left.(\mathrm{ndc})_{3}\right] \cdot \mathrm{CH}_{3} \mathrm{CN}(3)$ and $\left[\left\{\mathrm{Li}_{2} \mathrm{Zn}_{2}(\mathrm{dmf})(\mathrm{py})_{2}\right\}\left\{\mathrm{LiZn}(\mathrm{dmf})_{2}\right\}_{2}\left(\mathrm{NO}_{2}-\mathrm{bdc}\right)_{6}\right] \cdot 5 \mathrm{DMF}$ (4). The approach involved the use of a presynthesized $\left[\mathrm{Li}_{2} \mathrm{Zn}_{2}(\mathrm{piv})_{6}(\mathrm{py})_{2}\right]$ heterometallic complex which retains its geometry in the final structure during the reactions. This approach is one of the best options for so called rational design of desirable structures. We have shown the effect of substituents in the benzene ring of the linker on the preservation of $\left\{\mathrm{Li}_{2} \mathrm{Zn}_{2}\right\}$ core. For frameworks $\mathbf{1}$ and $\mathbf{2}$ the luminescence properties were examined and efficient quenching of ligand luminescence was shown for inclusion compound nitrobenzene@1. The obtained results demonstrate the excellent future perspectives of using presynthesized complexes for the synthesis of new materials with tailored structures.

Supplementary Materials: The following are available online at https:/ /www.mdpi.com/2304-674 0/9/1/4/s1, Table S1: List of selected angles and bond distances for starting complex and compounds 1-4, Figure S1: (a) Pore representation in $\mathbf{1}$ with both disordered counterions; (b) Pore representation in $\mathbf{1}$ with the first type of partly occupied counterions fixed; (c) Pore representation in $\mathbf{1}$ the second type of partly occupied counterions fixed; (d) Pore representation in $\mathbf{1}$ without all counterions. Pore inner surface is shown in pink, outer surface-in blue. Framework and counterions are shown in dark blue, Figure S2: (a) Pore representation in 2; (b) Pore representation in 3; (c) Pore representation in 4. Pore inner surface is shown in pink, outer surface-in blue. Framework is shown in dark blue. Figure S3: IR spectrum of compound 1, Figure S4: IR spectrum of compound 2, Figure S5: IR 
spectrum of compound 3, the CIF and the checkCIF output files are included in the Supplementary Materials.

Author Contributions: Conceptualization, methodology, writing-original draft preparation, writingreview and editing, A.S. and M.B.; investigation, A.S., E.D., D.S., A.R., K.K., writing-review and editing, V.F. All authors have read and agreed to the published version of the manuscript.

Funding: This research was funded by The Russian Science Foundation, grant number 19-73-00171.

Institutional Review Board Statement: Not applicable.

Informed Consent Statement: Not applicable.

Data Availability Statement: Data is contained within the article or supplementary material.

Conflicts of Interest: The authors declare no conflict of interest.

\section{References}

1. Ryu, U.; Jee, S.; Rao, P.C.; Shin, J.; Ko, C.; Yoon, M.; Park, K.S.; Choi, K.M. Recent advances in process engineering and upcoming applications of metal-organic frameworks. Coord. Chem. Rev. 2021, 426, 213544. [CrossRef] [PubMed]

2. Lai, C.; Wang, Z.; Qin, L.; Fu, Y.; Li, B.; Zhang, M.; Liu, S.; Li, L.; Yi, H.; Zhou, X.; et al. Metal-organic frameworks as burgeoning materials for the capture and sensing of indoor VOCs and radon gases. Coord. Chem. Rev. 2021, 427, 213565. [CrossRef]

3. Wang, H.; Liu, Y.; Li, J. Designer Metal-Organic Frameworks for Size-Exclusion-Based Hydrocarbon Separations: Progress and Challenges. Adv. Mater. 2020, 32, 2002603. [CrossRef] [PubMed]

4. Wang, T.; Lin, E.; Peng, Y.-L.; Chen, Y.; Cheng, P.; Zhang, Z. Rational design and synthesis of ultramicroporous metal-organic frameworks for gas separation. Coord. Chem. Rev. 2020, 423, 213485. [CrossRef]

5. Sapianik, A.A.; Kovalenko, K.A.; Samsonenko, D.G.; Barsukova, M.O.; Dybtsev, D.N.; Fedin, V.P. Exceptionally effective benzene/cyclohexane separation using a nitro-decorated metal-organic framework. Chem. Commun. 2020, 59, 8241-8244. [CrossRef] [PubMed]

6. Alzamly, A.; Bakiro, M.; Ahmed, S.H.; Alnaqbi, M.A.; Nguen, H.L. Rare-earth metal-organic frameworks as advanced catalytic platforms for organic synthesis. Coord. Chem. Rev. 2020, 425, 213543. [CrossRef]

7. Zhao, Y.; Li, D. Lanthanide-functionalized metal-organic frameworks as ratiometric luminescent sensors. J. Mater. Chem. C 2020, 8, 12739-12754. [CrossRef]

8. Liu, S.; Lai, C.; Liu, X.; Li, B.; Zhang, C.; Qin, L.; Huang, D.; Yi, H.; Zhang, M.; Li, L.; et al. Metal-organic frameworks and their derivatives as signal amplification elements for electrochemical sensing. Coord. Chem. Rev. 2020, 424, 213520. [CrossRef]

9. Haldar, R.; Bhattacharyya, S.; Maji, T.K. Luminescent metal-organic frameworks and their potential applications. J. Chem. Sci. 2020, 132, 99. [CrossRef]

10. Yang, D.; Chen, Y.; Su, Z.; Zhang, X.; Zhang, W.; Srinivas, K. Organic carboxylate-based MOFs and derivatives for electrocatalytic water oxidation. Coord. Chem. Rev. 2021, 428, 213619. [CrossRef]

11. Gong, W.; Liu, Y.; Li, H.; Cui, Y. Metal-organic frameworks as solid Brønsted acid catalysts for advanced organic transformations. Coord. Chem. Rev. 2020, 420, 213400. [CrossRef]

12. Zhang, T.; Lin, W. Metal-organic frameworks for artificial photosynthesis and photocatalysis. Chem. Soc. Rev. 2014, $43,5982$. [CrossRef] [PubMed]

13. Kung, C.-W.; Han, P.-C.; Chuang, C.-H.; Wu, K.C.-W. Electronically conductive metal-organic framework-based materials. APL Mater. 2019, 7, 110902. [CrossRef]

14. Cai, Z.-X.; Wang, Z.-L.; Kim, J.; Yamauchi, Y. Hollow Functional Materials Derived from Metal-Organic Frameworks: Synthetic Strategies, Conversion Mechanisms, and Electrochemical Applications. Adv. Mater. 2019, 31, 1804903. [CrossRef]

15. Chuang, C.-H.; Kung, C.-W. Metal-Organic Frameworks toward Electrochemical Sensors: Challenges and Opportunities. Electroanalysis 2020, 32, 1885. [CrossRef]

16. Karmakar, A.; Paul, A.; Pombeiro, A.J.L. Recent advances on supramolecular isomerism in metal organic frameworks. CrystEngComm 2017, 19, 4666-4695. [CrossRef]

17. Sapianik, A.A.; Fedin, V.P. Main Approaches to the Synthesis of Heterometallic Metal-Organic Frameworks. Russ. J. Coord. Chem. 2020, 46, 443-457. [CrossRef]

18. Dybtsev, D.N.; Sapianik, A.A.; Fedin, V.P. Pre-synthesized secondary building units in the rational synthesis of porous coordination polymers. Mendeleev Commun. 2017, 27, 321-331. [CrossRef]

19. Fei, H.; Cahill, J.F.; Prather, K.A.; Cohen, S.M. Tandem Postsynthetic Metal Ion and Ligand Exchange in Zeolitic Imidazolate Frameworks. Inorg. Chem. 2013, 52, 4011-4016. [CrossRef]

20. Ji, Z.; Wang, H.; Canossa, S.; Wuttke, S.; Yaghi, O.M. Pore Chemistry of Metal-Organic Frameworks. Adv. Funct. Mater. 2020, 30, 2000238. [CrossRef]

21. Hao, J.-N.; Xu, X.-Y.; Lian, X.; Zhang, C.; Yan, B. A Luminescent 3d-4f-4d MOF Nanoprobe as a Diagnosis Platform for Human Occupational Exposure to Vinyl Chloride Carcinogen. Inorg. Chem. 2017, 56, 11176-11183. [CrossRef] [PubMed] 
22. Sun, N.; Yan, B. $\mathrm{Ag}^{+}$-induced photoluminescence enhancement in lanthanide post-functionalized MOFs and $\mathrm{Ag}^{+}$sensing. Phys. Chem. Chem. Phys. 2017, 19, 9174-9180. [CrossRef] [PubMed]

23. Perfecto-Irigaray, M.; Albo, J.; Beobide, G.; Castillo, O.; Irabien, A.; Pérez-Yáñez, S. Synthesis of heterometallic metal-organic frameworks and their performance as electrocatalyst for $\mathrm{CO}_{2}$ reduction. RSC Adv. 2018, 8, 21092-21099. [CrossRef]

24. Kim, M.; Cahill, J.F.; Fei, H.; Prather, K.A.; Cohen, S.M. Postsynthetic Ligand and Cation Exchange in Robust Metal-Organic Frameworks. J. Am. Chem. Soc. 2012, 134, 18082-18088. [CrossRef] [PubMed]

25. Liu, Q.; Sun, N.; Gao, M.; Deng, C.-H. Magnetic Binary Metal-Organic Framework as a Novel Affinity Probe for Highly Selective Capture of Endogenous Phosphopeptides. ACS Sustain. Chem. Eng. 2018, 6, 4382-4389. [CrossRef]

26. Cui, P.; Wang, P.; Zhao, Y.; Sun, W.-Y. Fabrication of Desired Metal-Organic Frameworks via Postsynthetic Exchange and Sequential Linker Installation. Cryst. Growth Des. 2019, 19, 1454-1470. [CrossRef]

27. Du, J.-J.; Zhang, X.; Zhou, X.-P.; Li, D. Robust heterometallic MOF catalysts for the cyanosilylation of aldehydes. Inorg. Chem. Front. 2018, 5, 2772-2776. [CrossRef]

28. Cheng, X.; Jiang, Z.; Cheng, X.; Guo, X.; Tang, L.; Yang, H.; Wu, H.; Pan, F.; Zhang, P.; Cao, X.; et al. Bimetallic metal-organic frameworks nanocages as multi-functional fillers for water-selective membranes. J. Mem. Sci. 2018, 545, 19-28. [CrossRef]

29. Rubio-Giménez, V.; Waerenborgh, J.C.; Clemente-Juan, J.M.; Martí-Gastaldo, C. Spontaneous Magnetization in Heterometallic NiFe-MOF-74 Microporous Magnets by Controlled Iron Doping. Chem. Mater. 2017, 29, 6181-6185. [CrossRef]

30. Han, Y.; Zheng, H.; Liu, K.; Wang, H.; Huang, H.; Xie, L.-H.; Wang, L.; Li, J.-R. In-Situ Ligand Formation-Driven Preparation of a Heterometallic Metal-Organic Framework for Highly Selective Separation of Light Hydrocarbons and Efficient Mercury Adsorption. ACS Appl. Mater. Interfaces 2016, 8, 23331-23337. [CrossRef]

31. Hu, H.-C.; Kang, X.-M.; Cao, C.-S.; Cheng, P.; Zhao, B. First tetrazole-bridged d-f heterometallic MOFs with a large magnetic entropy change. Chem. Commun. 2015, 51, 10850-10853. [CrossRef] [PubMed]

32. Zhou, W.; Huang, D.-D.; Wu, Y.-P.; Zhao, J.; Wu, T.; Zhang, J.; Li, D.-S.; Sun, C.; Feng, P.; Bu, X. Stable Hierarchical BimetalOrganic Nanostructures as HighPerformance Electrocatalysts for the Oxygen Evolution Reaction. Angew. Chem. Int. Ed. 2019, 58, 4227-4237. [CrossRef] [PubMed]

33. Bratsos, I.; Tampaxis, C.; Spanopoulos, I.; Demitri, N.; Charalambopoulou, G.; Vourloumis, D.; Steriotis, T.A.; Trikalitis, P.N. Heterometallic In(III)-Pd(II) Porous Metal-Organic Framework with Square-Octahedron Topology Displaying $\mathrm{High}_{2} \mathrm{CO}_{2}$ Uptake and Selectivity toward $\mathrm{CH}_{4}$ and $\mathrm{N}_{2}$. Inorg. Chem. 2018, 57, 7244-7251. [CrossRef]

34. Li, C.; Tang, H.; Fang, Y.; Xiao, Z.; Wang, K.; Wu, X.; Niu, H.; Zhu, C.; Zhou, H. Bottom-Up Assembly of a Highly Efficient Metal-Organic Framework for Cooperative Catalysis. Inorg. Chem. 2018, 57, 13912-13919. [CrossRef] [PubMed]

35. Muldoon, P.F.; Liu, C.; Miller, C.C.; Koby, S.B.; Jarvi, A.G.; Luo, T.-Y.; Saxena, S.; O'Keeffe, M.O.; Rossi, N.L. Programmable Topology in New Families of Heterobimetallic Metal-Organic Frameworks. J. Am. Chem. Soc. 2018, 140, 6194-6198. [CrossRef] [PubMed]

36. Sapianik, A.A.; Lutsenko, I.A.; Kiskin, M.A.; Sidorov, A.A.; Eremenko, I.L.; Samsonenko, D.G.; Dybtsev, D.N.; Fedin, V.P. Heterometallic molecular complex $\left[\mathrm{Co}_{2} \mathrm{Gd}\left(\mathrm{NO}_{3}\right)(\mathrm{piv})_{6}(\mathrm{py})_{2}\right]$ and coordination polymer $\left[\left\{\mathrm{CoGd}(\mathrm{dma})_{2}\right\}_{2}(\mathrm{bdc})_{5}\right] \cdot 4 \mathrm{DMA}$ : The synthesis, structure, and properties. Russ. Chem. Bull. 2016, 65, 2601-2606. [CrossRef]

37. Lytvynenko, A.S.; Kolotilov, S.V.; Kiskin, M.A.; Cador, O.; Golhen, S.; Aleksandrov, G.G.; Mishura, A.M.; Titov, V.E.; Ouahab, L.; Eremenko, I.L.; et al. Redox-Active Porous Coordination Polymers Prepared by Trinuclear Heterometallic Pivalate Linking with the Redox-Active Nickel(II) Complex: Synthesis, Structure, Magnetic and Redox Properties, and Electrocatalytic Activity in Organic Compound Dehalogenation in Heterogeneous Medium. Inorg. Chem. 2018, 57, 4970-4979. [CrossRef]

38. Sotnik, S.A.; Polunin, R.A.; Kiskin, M.A.; Kirillov, A.M.; Dorofeeva, V.N.; Gavrilenko, K.S.; Eremenko, I.L.; Novotortsev, V.M.; Kolotilov, S.V. Heterometallic Coordination Polymers Assembled from Trigonal Trinuclear $\mathrm{Fe}_{2} \mathrm{Ni}$-Pivalate Blocks and Polypyridine Spacers: Topological Diversity, Sorption, and Catalytic Properties. Inorg. Chem. 2015, 54, 5169-5181. [CrossRef]

39. Dorofeeva, V.N.; Kolotilov, S.V.; Kiskin, M.A.; Polunin, R.A.; Dobrokhotova, Z.V.; Cador, O.; Golhen, S.; Eremenko, I.L.; Novotortsev, V.M. 2D Porous Honeycomb Polymers versus Discrete Nanocubes from Trigonal Trinuclear Complexes and Ligands with Variable Topology. Chem. Eur. J. 2012, 18, 5006-5012. [CrossRef]

40. Polunin, R.A.; Kolotilov, S.V.; Kiskin, M.A.; Cador, O.; Golhen, S.; Shvets, O.V.; Ouahab, L.; Dobrokhotova, Z.V.; Ovcharenko, V.I.; Eremenko, I.L.; et al. Structural Flexibility and Sorption Properties of 2D Porous Coordination Polymers Constructed from Trinuclear Heterometallic Pivalates and 4,4'-Bipyridine. Eur. J. Inorg. Chem. 2011, 2011, 4985-4992. [CrossRef]

41. Sapianik, A.A.; Zorina-Tikhonova, E.N.; Kiskin, M.A.; Samsonenko, D.G.; Kovalenko, K.A.; Sidorov, A.A.; Eremenko, I.L.; Dybtsev, D.N.; Blake, A.J.; Argent, S.P.; et al. Rational Synthesis and Investigation of Porous Metal-Organic Framework Materials from a Preorganized Heterometallic Carboxylate Building Block. Inorg. Chem. 2017, 56, 1599-1608. [CrossRef] [PubMed]

42. Macrae, C.F.; Sovago, I.; Cottrell, S.J.; Galek, P.T.A.; McCabe, P.; Pidcock, E.; Platings, G.P.; Shields, G.P.; Stevens, J.S.; Towler, M.; et al. Mercury 4.0: From visualization to analysis, design and prediction. J. Appl. Cryst. 2020, 53, 226-235. [CrossRef] [PubMed]

43. Heine, J.; Muller-Buschbaum, K. Engineering Metal-based Luminescence in Coordination Polymers and Metal-Organic Frameworks. Chem. Soc. Rev. 2013, 42, 9232-9242. [CrossRef]

44. Han, L.-L.; Hu, T.-P.; Mei, K.; Guo, Z.-M.; Yin, C.; Wang, Y.X.; Zheng, J.; Wang, X.-P.; Sun, D. Solvent-controlled three families of $\mathrm{Zn}(\mathrm{II})$ coordination compounds: Synthesis, crystal structure, solvent-induced structural transformation, supramolecular isomerism and photoluminescence. Dalton Trans. 2015, 44, 6052-6061. [CrossRef] [PubMed] 
45. Goldsworthy, J.S.; Staples, R.J.; LaDuca, R.L. Luminescent zinc terephthalate coordination polymers with pyridylnicotinamide ligands: Effect of added base and nitrogen donor disposition on topology. J. Molec. Struct. 2014, 1062, 116-124. [CrossRef]

46. Sapianik, A.A.; Kiskin, M.A.; Samsonenko, D.G.; Ryadun, A.A.; Dybtsev, D.N.; Fedin, V.P. Luminescent detection by coordination polymers derived from a pre-organized heterometallic carboxylic building unit. Polyhedron 2018, 145, 145-153. [CrossRef]

47. Sapianik, A.A.; Kiskin, M.A.; Kovalenko, K.A.; Samsonenko, D.G.; Dybtsev, D.N.; Audebrand, N.; Sun, Y.; Fedin, V.P. Rational synthesis and dimensionality tuning of MOFs from preorganized heterometallic molecular complexes. Dalton Trans. 2019, 48, 3676-3686. [CrossRef]

48. Sapianik, A.A.; Semenenko, E.E.; Samsonenko, D.G.; Dybtsev, D.N.; Fedin, V.P. Crystal Structure of Coordination Polymers Based on A Heterometallic Carboxylate Complex. J. Struct. Chem. 2018, 59, 487-493. [CrossRef]

49. Sapianik, A.A.; Smirnov, K.D.; Barsukova, M.O.; Samsonenko, D.G.; Fedin, V.P. Crystal Structures of Compounds Obtained in Reactions of Heterometallic Pivalate Complexes with Dicarboxylic Acids. J. Struct. Chem. 2019, 60, 609-616. [CrossRef]

50. Sapianik, A.A.; Dudko, E.R.; Samsonenko, D.G.; Fedin, V.P. Crystal Structures of Metal-Organic frameworks obtained from a heterometallic pivalate complex. J. Struct. Chem. 2020, 61, 2064-2071.

51. CrysAlisPro 1.171.40.84a. Rigaku Oxford Diffraction; Rigaku Corporation: The Woodlands, TX, USA, 2020.

52. Kabsch, W. XDS. Acta Crystallogr. Sect. D 2010, 66, 125-132. [CrossRef] [PubMed]

53. Sheldrick, G.M. SHELXT-Integrated space-group and crystal-structure determination. Acta Crystallogr. Sect. A 2015, 71, 3-8. [CrossRef] [PubMed]

54. Sheldrick, G.M. Crystal structure refinement with SHELXL. Acta Crystallogr. Sect. C 2015, 71, 3-8. [CrossRef]

55. Spek, A.L. PLATON SQUEEZE: A tool for the calculation of the disordered solvent contribution to the calculated structure factors. Acta Crystallogr. Sect. C 2015, 71, 9-18. [CrossRef] [PubMed] 